\title{
Management of chronic hepatitis B: Canadian Association for the Study of the Liver consensus guidelines
}

\author{
Carla S Coffin MD MSc, FRCPC ${ }^{1}$, Scott K Fung MD FRCPC ${ }^{2}$, Mang M Ma MD FRCPC ${ }^{3}$
}

\begin{abstract}
CS Coffin, SK Fung, MM Ma. Management of chronic hepatitis B: Canadian Association for the Study of the Liver consensus guidelines. Can J Gastroenterol 2012;26(12):917-938.
\end{abstract}

Chronic hepatitis B (CHB) is a dynamic disease that is influenced by host and virological factors. The management of $\mathrm{CHB}$ has become more complex with the increasing use of long-term oral nucleos/tide analogue antiviral therapies and the availability of novel diagnostic assays. Furthermore, there is often a lack of robust data to guide optimal management such as the selection of therapy, duration of treatment, potential antiviral side effects and the treatment of special populations. In November 2011, the Canadian Liver Foundation and the Canadian Association for the Study of the Liver convened a consensus conference to review the literature and analyze published data, including other international expert guidelines on $\mathrm{CHB}$ management. The proceedings of the consensus conference are summarized and provide updated clinical practice guidelines to assist Canadian health care providers in the prevention, diagnosis, assessment and treatment of $\mathrm{CHB}$.

Key Words: Antiviral therapy; Canadian; Chronic hepatitis B; Hepatitis B virus infection; Management

Chronic hepatitis B infection remains a major public health burden in Canada. Since the 2007 Canadian Association for the Study of the Liver (CASL) update in the management of chronic hepatitis $B$ virus (HBV) (1), our knowledge of the natural history of chronic hepatitis $B$, the assessment of infected patients and the treatment of the virus have improved. In November 2011, the CASL and the Canadian Liver Foundation organized the consensus conference to develop a new hepatitis $\mathrm{B}$ guideline to assist clinicians and health care providers in providing health services and treatment to chronic hepatitis B patients.

The consensus committee addressed the following questions:

1. What is the epidemiology and public health burden of chronic hepatitis B infection in Canada?

2. What would be an ideal vaccination policy to prevent hepatitis B infection?

3. Who should be screened for chronic hepatitis B infection?

4. What is the natural history of chronic hepatitis B infection?

5. How should chronic hepatitis B infection be assessed?

6. What are the special laboratory tests that may be useful to guide management decision?

7. Who should receive treatment?

8. What are the first-line drugs to treat chronic hepatitis B infection?

\section{La prise en charge de l'hépatite $B$ chronique : les lignes directrices consensuelles de l'Association canadienne pour l'étude du foie}

L'hépatite B chronique (HBC) est une maladie dynamique influencée par l'hôte et les facteurs virologiques. La prise en charge de l'HBC s'est compliquée avec l'utilisation accrue des analogues de nucléosides et de nucléotides antiviraux sur une longue période et la disponibilité de méthodes diagnostiques novatrices. De plus, on manque souvent de données solides pour orienter une prise en charge optimale, telle que la sélection de la thérapie, la durée du traitement, les effets secondaires potentiels des antiviraux et le traitement des populations particulières. En novembre 2011, la Fondation canadienne du foie et l'Association canadienne pour l'étude du foie ont organisé une conférence consensuelle pour procéder à une analyse de la bibliographie et des données publiées, y compris d'autres lignes directrices internationales d'experts sur la prise en charge de l'HBC. Les débats de la conférence consensuelle sont résumés et donnent lieu à une mise à jour des lignes directrices cliniques pour aider les dispensateurs de soins canadiens à prévenir, diagnostiquer, évaluer et traiter l'HBC.

\section{How should groups with special needs be assessed and treated?}

The present report presents the proceeding of the consensus development conference and the update will focus on answering the above questions.

\section{PROCESS}

The process used to arrive at consensus was as follows: An Organizing Committee was appointed by the CASL and the Canadian Liver Foundation. This committee invited expert speakers to review the current literature on different topics. After the presentation, questions from the audience were addressed. A Writing Committee, selected by the Organizing Committee, assessed the information from the presentations and from other sources, and prepared a document that was circulated to the speakers for comment. The strength of the recommendations and the evidence supporting the recommendations have been evaluated and graded according to the grading system adapted from the American College of Cardiology and the American Heart Association Practice Guidelines and the Grading of Recommendations Assessment Development and Evaluation (GRADE) system (2-8) (Table 1). The report presents the recommendations representing the best medical practice in the assessment and the management of chronic hepatitis B infection.

All authors contributed equally.

${ }^{1}$ Department of Medicine, University of Calgary, Calgary, Alberta; ${ }^{2}$ Department of Medicine, University of Toronto, Toronto, Ontario; ${ }^{3}$ Department of Medicine, University of Alberta, Edmonton, Alberta

Correspondence: Dr Mang M Ma, Department of Medicine, University of Alberta, Zeidler Ledcor Centre, Edmonton, Alberta T6G 2 X8.

Telephone 780-492-8146, e-mail mang.ma@ualberta.ca

Received for publication July 22, 2012. Accepted August 12, 2012 


\section{TABLE 1}

\section{Adapted grading system for recommendations}

\begin{tabular}{l}
\hline Classification Description \\
\hline Class of evidence \\
\hline $\begin{array}{c}\text { Strong recommendation } 1 \\
\text { There is high-quality evidence that supports the usefulness } \\
\text { or efficacy of a given diagnostic test or treatment }\end{array}$
\end{tabular}

Class 2 On the balance of evidence and opinion, there is support in favour of the usefulness or efficacy of a given diagnostic test or treatment

Class $2 a \quad$ Weight of evidence/opinion is in favour of usefulness/ efficacy

Class $2 \mathrm{~b} \quad$ Usefulness/efficacy is less well established by evidence/ opinion

Class $3 \quad$ Cannot be recommended

Conditions for which there is evidence and/or general agreement that a diagnostic evaluation, procedure or treatment is not useful or effective and in some cases may be harmful

\section{Grade of evidence}

Level A High-quality evidence from multiple randomized clinical trials or meta-analyses

Level B Data from a single randomized trial, or nonrandomized studies

Further information might have an impact on our confidence of the practice

Level C

Consensus opinion of experts, or case studies

Further information is needed to support the practice

\section{CANADIAN EPIDEMIOLOGY AND PUBLIC HEALTH BURDEN OF HEPATITIS B INFECTION}

Hepatitis $B$ is one of the most common infections in the world, with more than 360 million chronic carriers (9). In Canada, chronic hepatitis B infection is primarily a disease of immigrants from endemic countries. In a childhood HBV surveillance study, the nonCanadian-born children had an RR 12 times higher than that of Canadian-born children (10). There had been attempts to estimate the number of hepatitis B carriers in Canada. Statistics Canada estimated the number of HBV-infected individuals to be approximately 600,000 and this was based on the assumption of a $6 \%$ rate in immigrants, a $1 \%$ rate in Canadian-born individuals and a $4 \%$ rate in Aboriginals (11). In a recent review of available data (12), the estimated overall prevalence of HBV carriers in the general population in Canada is approximately $2 \%$ and the high-risk groups include immigrants, Aboriginals and street-connected individuals (12). Because immigrants and street-connected individuals tend to live in large urban centres, the seroprevalence rate is not uniformly distributed across the country.

Chronic hepatitis B can progress to end-stage liver disease and there is also a significant risk of hepatocellular carcinoma (HCC) development. After decades of infection, the rate of cirrhosis or chronic liver failure is $20 \%$ to $25 \%$, and the rate of HCC development is approximately $5 \%(13,14)$. In a recent Ontario Burden of Infectious Disease Study (15), hepatitis B was the fourth-ranked pathogen causing significant years of life lost due to premature mortality.

Chronic HBV infection is often asymptomatic and diagnosed late unless at-risk individuals are screened for the infection. Symptoms indicate a late stage of infection and complications may have already developed. When these complications of chronic liver failure or HCC develop, they are more difficult to reverse and are often fatal. Chronic hepatitis B infection will remain a public health problem and major health resource utilization in Canada over the next several decades.

\section{Recommendation}

1. The Federal Ministry of Health and/or the provinces should support and develop structural programs to determine the numbers of HBV-infected individuals in the country, and facilitate the assessment and treatment of chronically infected patients (Class 2a, Level B).

\section{HEPATITIS B VACCINATION}

The ideal hepatitis B vaccination policy should provide immune protection against hepatitis B infection in infancy when the risk of chronic infection is highest and in adolescence when acute infection relating to the risk behaviours of intravenous drug use and unprotected sex can potentially occur.

The Canadian provinces of Alberta, Saskatchewan, Manitoba, Ontario, Quebec, Nova Scotia, and Newfoundland and Labrador offer universal vaccination of adolescents or preadolescents rather than universal neonatal vaccination. These provinces also use maternal screening to identify at-risk babies who should be vaccinated. This policy approach addresses the mother-to-infant transmission of the virus. However, it does not address that hepatitis $\mathrm{B}$ infection can be transmitted horizontally during childhood. In Canada, hepatitis B is a disease of immigrants and usually more than one family member are affected. The mother might not have the infection; however, another family member or sibling can have the infection and can transmit the virus to a child through unrecognized close contact with infectious body fluids. Although the virus is found mainly in the blood and serous fluids of an infected person, it can also be present in the saliva at concentrations 1000 to 10,000 times less than in blood. Population studies have documented that a significant portion of chronic hepatitis $B$ infection was acquired during infancy or early childhood $(16,17)$. The immunization strategy of providing adolescent vaccinations without offering neonatal vaccinations will miss the opportunity to prevent chronic infection in infants or young children when chronic infection can occur in $90 \%$ of infants and $25 \%$ to $50 \%$ of young children.

Successive Canadian consensus conferences on the management of chronic viral hepatitis have recommended neonatal hepatitis B vaccination (1). In 2001, British Columbia became the first province offering universal hepatitis B vaccination to infants and 'catch-up' adolescent vaccination. Since the implementation of this vaccination policy, the reported incidence of acute HBV infection in British Columbia continues to decline and the province has an annual incidence consistently below the national average (18). Currently, 171 of the 193 WHO members have implemented the policy of universal hepatitis B vaccination of infants (19). There is no reason that the 13 health care jurisdictions in Canada should not have a harmonized policy similar to the WHO.

The hepatitis B surface antibody (anti-HBs) titre decreases over time. After 10 years, more than one-third of children vaccinated during infancy will have anti-HBs titres below the accepted protective antibody level of $10 \mathrm{IU} / \mathrm{L}(20-22)$. However, most hepatitis B-vaccinated adults can mount a protective immune response even 18 years after receiving a primary series of infancy vaccinations. In groups at high risk of HBV infection, a low rate of infection is observed 18 years after vaccination $(23,24)$. Routine booster vaccination is not indicated in average-risk populations. For healthy adults who fail to respond to the first series of vaccines, additional doses of vaccine can stimulate the immune system, producing a protective antibody level in $50 \%$ to $70 \%$ of these adults.

At-risk adults who have negative hepatitis B surface antigen ( $\mathrm{HBs} \mathrm{Ag})$ and anti-HBs tests should receive hepatitis B vaccination (Table 2). Hepatitis B vaccination is also recommended for patients who have chronic liver disease other than hepatitis B even though the efficacy of vaccinating this population is not as pronounced $(25-27)$. These patients with liver disease may not be able to sustain a second injury to the liver, and having immunity against HBV may be beneficial. The Advisory Committee on Immunization Practices from the Centers for Disease Control and Prevention (Georgia, USA) also recommends all hepatitis B-unvaccinated diabetic adults 19 to 59 years of age be vaccinated against the virus (28). 
TABLE 2

\section{At-risk adults who are candidates for pre-exposure} prophylaxis

Health care providers, including dentists and staff, and emergency service workers

Household and sexual contacts of acute hepatitis B virus (HBV) cases and known HBV carriers, including those with daily close contact in child care settings

Residents and staff of institutions for the developmentally challenged Injection drug users

Men having sexual contact with men

Those who have unprotected sex with multiple new partners or with a history of sexually transmitted infections

Hemophiliacs and others receiving repeated infusions of blood or blood products

Hemodialysis patients ( $40 \mu \mathrm{g}$ of vaccine antigen per dose should be used)

Diabetic adults

Staff and inmates of correctional facilities

Populations or communities in which HBV is highly endemic

Travellers to hepatitis B-endemic areas

\section{Recommendations}

2. All Canadian provinces should harmonize the hepatitis B vaccination policy and implement universal neonatal or infant vaccination, with catch-up vaccination for those who have not yet received adolescent vaccination (Class 1, Level B).

3. Routine booster dose of HBV vaccination is not indicated in immune-competent individuals who had immune response to the primary series of vaccine (Class 2a, Level A).

4. Additional doses of vaccine should be offered to healthy adults who fail to respond after the first series of vaccines (Class 1 , Level A).

5. At-risk adults whose screening tests are negative for $\mathrm{HBsAg}$ and anti-HBs should receive hepatitis B vaccines (Class 1, Level A).

\section{SCREENING OF HIGH-RISK INDIVIDUALS TO IDENTIFY CHRONIC INFECTION}

Chronic hepatitis B infection is often asymptomatic for decades and screening is important in identifying infected individuals for transmission counselling, disease progression monitoring and treatment to prevent end-stage liver disease or untreatable HCC. In Canada, the majority of infants, children and adolescents have received the hepatitis $B$ vaccine, and the risk of chronic infection is very low. The risk groups include immigrants, Aboriginals and individuals who have potential risk factors for viral hepatitis or HIV infection (Table 3). These groups should be screened for chronic hepatitis B infection with $\mathrm{HBsAg}$, anti-HBs and hepatitis B core antibody (anti-HBc). If the HBsAg test is positive, the person should be fully assessed for chronic viral hepatitis and HIV infection. If the person is positive for anti-HBc only, a booster $\mathrm{HBV}$ vaccine should be given to assess for anamnestic immune response (29). If the booster vaccine cannot elicit an anti-HBs response, the person may have occult infection and the person can experience activation of hepatitis B during immunosuppression (30).

\section{Recommendation}

6. All high-risk individuals should be screened for chronic hepatitis B infection with $\mathrm{HBs} A g$, anti-HBs and anti-HBc (Class 2a, Level B).

\section{NATURAL HISTORY OF CHRONIC HEPATITIS B INFECTION}

Chronic hepatitis B infection has a complex natural history and is a dynamic disease that can change over time. It has been estimated that

\section{TABLE 3}

High-risk individuals who should be screened for chronic hepatitis B virus (HBV)

Immigrants as part of their routine preimmigration health care evaluation (especially from endemic countries/developing countries)

Nonvaccinated individuals whose parents were from HBV-endemic countries Household contacts of HBV carriers

Sexual contacts of HBV carriers

Persons with multiple sexual partners

Men who have sex with men

Persons who have used recreational or intravenous drugs

Inmates

Patients with chronic renal failure needing dialysis

Patients with abnormal alanine aminotransferase/aspartate aminotransferase

All pregnant women

Patients needing immune modulation therapy or those who will develop immunosuppression such as cancer chemotherapy

\section{TABLE 4}

Phases of hepatitis B virus (HBV) infection

\begin{tabular}{|c|c|c|c|c|c|}
\hline Phases & HBsAg & HBeAg & Anti-HBe & $\begin{array}{c}\text { ALT } \\
\text { pattern }\end{array}$ & HBV DNA \\
\hline Immune tolerant & Positive & Positive & Negative & Normal & $\begin{array}{l}\sim>2 \times 10^{4} \text { to } \\
>2 \times 10^{8} \mathrm{IU} / \mathrm{mL}\end{array}$ \\
\hline $\begin{array}{l}\text { Immune } \\
\text { clearance }\end{array}$ & Positive & Positive & Negative & $\begin{array}{l}\text { Normal or } \\
\text { elevated }\end{array}$ & $\begin{array}{l}\sim>2 \times 10^{4} \text { to } \\
>2 \times 10^{8} \mathrm{IU} / \mathrm{mL}\end{array}$ \\
\hline Inactive disease & Positive & Negative & Positive & Normal & $<200 \mathrm{IU} / \mathrm{mL}$ \\
\hline $\begin{array}{l}\text { HBeAg-negative } \\
\text { chronic hepatitis }\end{array}$ & Positive & Negative & Positive & $\begin{array}{l}\text { Normal or } \\
\text { elevated }\end{array}$ & $\begin{array}{l}\text { Undetectable to } \\
>2 \times 10^{8} \mathrm{IU} / \mathrm{mL}\end{array}$ \\
\hline $\begin{array}{l}\text { Resolution of } \\
\text { infection }\end{array}$ & Negative & Negative & Positive & Normal & Undetectable \\
\hline
\end{tabular}

ALT Alanine aminotransferase; Anti-HBe Hepatitis $B$ e antibody; $H B e A g$ Hepatitis $B$ e antigen; HBsAg Hepatitis $B$ surface antigen

$25 \%$ of the carriers will develop significant chronic liver disease or HCC.

The natural history of HBV infection can progress through five phases (Table 4). Patients may not go through every phase and the duration of each phase is highly variable in each patient. In motherto-infant, perinatal or childhood infection, an immune tolerant phase is normal and may last 10 years to more than 20 years. During the immune-tolerant phase, the patients do not have active hepatitis. Alanine aminotransferase (ALT) levels are persistently low and HBV DNA levels are very high. The liver biopsy shows no or minimal inflammation. In clinical practice, biopsies are seldom performed to diagnose this phase and clinicians rely on a persistently low ALT levels to make the diagnosis. This practice is not completely reliable because inflammation can occur in the setting of high-normal ALT, and intermittent ALT testing may miss short-lived periods of elevated ALT levels. A normal transient elastography study will be useful to confirm that the patients are indeed in the immune-tolerant phase.

The immune clearance phase can last less than five years to more than 25 years. ALT levels are elevated and HBV DNA level decreases. During this phase, the patients can develop cirrhosis, or seroconversion from hepatitis $\mathrm{B}$ e antigen ( $\mathrm{HBeAg}$ )-positive to hepatitis $\mathrm{B}$ e antibody (anti-HBe)-positive. The predictors of seroconversion are high ALT, low HBV DNA, patient age younger than 40 years and absence of cirrhosis (31-33). After the immune-clearance phase, the infection may become inactive or may evolve into HBeAg-negative chronic hepatitis after a quiescent phase. For the patients who are permanently in an inactive phase, ALT levels are normal and the HBV DNA level is low or nondetectable. These patients tend to have a good prognosis. Patients who have established cirrhosis before $\mathrm{HBeAg}$ seroconversion continue to have a high risk of HCC. 
Patients who experience reactivation of the virus after $\mathrm{HBeAg}$ seroconversion can develop HBeAg-negative chronic hepatitis. These patients tend to have fluctuating ALT and HBV DNA levels. A yearly single finding of normal ALT and HBV DNA $<2000 \mathrm{IU} / \mathrm{mL}$ does not prove that the patients are still in the inactive carrier state. These $\mathrm{HBeAg-negative} \mathrm{chronic} \mathrm{hepatitis} \mathrm{patients} \mathrm{are} \mathrm{at} \mathrm{risk} \mathrm{of} \mathrm{developing}$ end-stage liver disease and HCC. This means that patients who have inactive disease for years must continue to undergo regular follow-up for the detection of reactivation. Spontaneous resolution of the infection with clearance of HBsAg occurs in only $0.5 \%$ to $0.8 \%$ of chronic carriers per year $(34,35)$.

The risks for cirrhosis and HCC development correlate with the severity of chronic inflammation or fibrosis, HBV DNA level, duration of infection, male sex and concomitant liver diseases such as alcoholic liver disease. The rate of progression to end-stage liver disease or HCC occurs at a rate of $5 \%$ to $10 \%$ per year, with an annual death rate of $20 \%$ to $50 \%$ after the development of complications (36-38).

\section{Recommendation}

7. Chronic hepatitis B infection has a complex natural history and is a dynamic disease that can change over time to more serious disease with risk of liver failure and HCC. These patients need to be monitored at least yearly or more frequently if the disease is progressing (Class 2a, Level A).

\section{SPECIAL LABORATORY ASSESSMENT OF CHRONIC HEPATITIS B INFECTION}

There are special laboratory tests that are crucial or helpful tools in the evaluation of chronic hepatitis B patients and in the guidance of treatment decisions. This section discusses these tests.

\section{HBV DNA viral load testing}

HBV DNA viral load testing is a crucial tool to monitor and manage chronic hepatitis B patients. HBV DNA level is a predictor of cirrhosis and HCC development (39-44). The HBV DNA International Unit (IU/mL) has been adopted to improve comparability among commercial assays (44). These assays have good dynamic range to enable accurate determination of the viral DNA levels in patients. HBV DNA measurements will usually need to be repeated at intervals of three to six months to monitor disease evolution. During treatment of the infection, HBV DNA measurements are frequently needed to monitor treatment response and noncompliance, and assess for treatmentresistant mutant development. Therefore, there should be no restriction on the frequency of HBV DNA viral load testing.

\section{Recommendation \\ 8. All clinicians should have access to HBV DNA testing and there should be no restriction on the frequency of HBV testing (Class 1, Level A).}

Transient elastography and noninvasive modalities to assess hepatic injury in chronic hepatitis B patients

Transient elastography is a noninvasive ultrasound test measuring liver stiffness (LS). Health Canada approved the use of transient elastography to determine liver fibrosis in 2009. The LS measurement is a good predictor of fibrosis and is an alternative to liver biopsy in determining liver fibrosis (45). The test is quick and easy to perform. With proper training, it is also operator independent. Because it is noninvasive, it is an ideal test to monitor fibrosis progression in chronic hepatitis B patients; changes in LS could be a reflection of liver disease progression. There is an approximately $5 \%$ test failure rate and these failures are commonly related to obesity and narrow intercostal spaces in small individuals. Using a cut-off of 7.1 KPa, transient elastography has a very high negative predictive value $(>90 \%)$ in predicting significant fibrosis or cirrhosis. Compared with the aspartate aminotransferase (AST)/platelet ratio index and the FIB-4 test, transient elastography is better in predicting significant fibrosis and cirrhosis (46).
In chronic hepatitis B patients, intermittent, severe flares of hepatitis can occur. During these flares, the LS values can increase significantly and the stiffness value changes may not imply progression of fibrosis if the testing is performed during flares $(47,48)$. The overall trend is more important than a single measurement. It is possible to use an algorithm of LS measurement to guide the selection of patients for treatment $(46,49)$.

Other noninvasive, serum-based tests for detection of hepatic fibrosis (eg, Fibrotest, FibroSpect II, AST/platelet ratio index, Forns fibrosis index, FIB-4) can be used in the assessment of chronic hepatitis $\mathrm{B}$ infection. However, there is less information available to guide the use of these tests in chronic hepatitis B patients.

\section{Recommendation \\ 9. Clinicians should have access to transient elastography testing, a noninvasive procedure that can help to assess fibrosis and monitor chronic hepatitis B progression (Class 2a, Level B).}

\section{Liver biopsy}

Liver biopsy is often performed in diagnosing liver disease, assessing severity or prognosis, and guiding management of patients with liver diseases. It is the current reference standard. The majority of liver biopsies are obtained by a clinical examination-guided transcutaneous, transthoracic approach or an ultrasound-guided subcostal approach. The transvenous or transjugular approach is occasionally used in patients with significant risk of hemorrhage. Pain is the most common complication of transcutaneous liver biopsy and can occur in up to $85 \%$ of cases (50). The pain is usually mild to moderate and can be treated with small doses of narcotics. The most significant complication of liver biopsy is intraperitoneal hemorrhage, which, when severe, can be fatal $(51,52)$. Severe postliver biopsy hemorrhage has been estimated to occur in between one in 2500 to one in 10,000 biopsies. Mortality after liver biopsy is rare and is usually related to severe hemorrhage. Complications such as pneumothorax, hemothorax and gallbladder puncture are less likely to occur with ultrasound-guided liver biopsy.

To justify the risk of the liver biopsy procedure, the information from the histological assessment of the liver will be important in guiding the management of the patient. It is possible that patients can have more than one liver condition. Liver biopsy is important in this setting. In cases of discrepancy between noninvasive fibrosis testing and clinical impression, liver biopsy will also be useful.

Biopsy sampling error can occur, especially if the biopsy size is inadequate and has fewer than 11 evaluable portal tracts $(53,54)$. The biopsy result should be interpreted in conjunction with clinical, laboratory and imaging assessment.

\section{Recommendation}

10. Clinicians should consider obtaining a liver biopsy if there is a possibility of coexisting liver disease, or uncertainty of the severity of liver disease after laboratory, imaging and noninvasive fibrosis testing (Class 1, Level B).

\section{Quantification of HBsAg}

Serum HBsAg concentration reflects the number of hepatitis B covalently closed circular genomes (cccDNA), the transcriptional activity of cccDNA and the host immune response against the virus. Not too surprisingly, HBsAg level varies across HBV genotypes and during different phases of infection (55). The HBsAg level is higher during the immune tolerant phase compared with the immune clearance phase. The HBsAg level tends to be lower in patients with inactive infection. Currently there are two commercial assays, the Architect QT assay (Abbott Laboratories, USA) and the Elecsys HBsAg II Quant assay (Roche Diagnostics, Switzerland). There is a good correlation between the HBsAg quantification by these two assays $(56,57)$.

In the recent literature, $\mathrm{HBs} A g$ concentration monitoring has been shown to be helpful in the management and in guiding treatment of chronic hepatitis B infection. In inactive HBV carriers, the $\mathrm{HBs} \mathrm{Ag}$ level tends to be significantly lower than that of patients with chronic 
hepatitis, and a low level of HBsAg is also a predictor of HBsAg seroclearance (58-60).

HBsAg monitoring may have a role in pegylated interferon (PEG IFN) treatment of chronic hepatitis $\mathrm{B}$. In patients who received PEG IFN treatment for $\mathrm{HBeAg-positive} \mathrm{chronic} \mathrm{hepatitis,} \mathrm{early}$ decline of $\mathrm{HBs} A g$ level was associated with $\mathrm{HBeAg}$ seroconversion and sustained response post-treatment (61). At week 12 of PEG IFN treatment, a lack of HBsAg level decline was a predictor of poor IFN treatment response (61). For $\mathrm{HBeAg}$-positive patients who do not experience a decline in HBV DNA and HBsAg levels during week 12 of PEG IFN treatment, the likelihood of response will be small and treatment discontinuation can be considered. In patients who received PEG IFN treatment for HBeAg-negative chronic hepatitis, HBsAg level decline at weeks 12 to 24 and end of treatment level were also predictors of response $(61,62)$.

\section{Recommendation}

11. Clinicians should have access to HBsAg quantification testing, which may help in the selection of patients for therapy and predicting response with interferon based therapy (Class 2a, Level B).

\section{HBV genotype testing}

The HBV genome is heterogeneous and can be grouped into eight recognized genotypes (A through $\mathrm{H}$ ) based on the criterion of $8 \%$ or more differences in DNA sequence variations in the HBV genome. HBV genotypes have a characteristic geographical distribution, with genotype A being common in Europe, North America and Africa, genotypes $\mathrm{B}$ and $\mathrm{C}$ in the Far East, genotype D being found worldwide, genotype $\mathrm{E}$ in Africa, genotype $\mathrm{F}$ in South America and Alaska, genotype $\mathrm{G}$ in North America and genotype $\mathrm{H}$ in Central America (6365). HBV genotype population studies have suggested there are differences in the natural history and clinical outcomes among different HBV genotypes. In the Far East, genotype B has been associated with less severe liver disease, lower rates of $\mathrm{HBeAg}$ reactivity and higher spontaneous $\mathrm{HBeAg}$ seroconversion than genotype $\mathrm{C}$ (66). Genotype $\mathrm{C}$ is associated with more frequent HCC development. Less information is available for genotypes A and D. Genotype A seems to have milder disease and cause less cirrhosis or HCC, and responds better to interferon treatment (67). Genotype D may be associated with higher rates of hepatoma and higher rates of post-transplant recurrence and mortality compared with genotype A (66). Genotypes C and D are associated with a lower response to interferon compared with genotypes $A$ and $B(67,68)$. HBV genotype testing can be useful in monitoring and guiding treatment of chronic hepatitis $B$ patients.

\section{Recommendation}

12. Clinicians should have access to HBV genotype testing, which helps in the selection of antiviral therapy and the prediction of response with interferon-based therapy (Class 2a, Level B).

\section{Assessment of chronic hepatitis B and selection of patients for} treatment

All HBsAg-positive patients should undergo a complete assessment with a detailed history including family history of viral hepatitis and HCC, risk factors for hepatitis B acquisition, alcohol use and a complete physical examination to detect signs of chronic liver disease. Laboratory evaluation should include serum ALT/AST, alkaline phosphatase, bilirubin, albumin, international normalized ratio, creatinine and complete blood count (CBC). Specific HBV testing should include HBsAg, $\mathrm{HBeAg}$, anti-HBe and HBV DNA levels. Patients should also be screened for hepatitis $\mathrm{C}$ virus (HCV) and HIV infection. Delta virus (hepatitis D virus [HDV]) infection testing should be performed in individuals who have a history of past or current intravenous drug use, or a history of sex with a past or present injection drug user, or from endemic countries with HDV infection. Anti-HDV testing should also be performed in patients with elevated ALT levels but have low to undetectable HBV DNA levels. A baseline abdominal ultrasound should be performed to look for signs of cirrhosis and the existence of HCC. If transient elastography testing is available, it will be a useful test to assess the severity of fibrosis and monitor for disease progression. A liver biopsy should be considered if there is uncertainty of the disease status or if there is a possibility of coexisting liver diseases.

Patients in whom the hepatitis is mild and treatment is not required will still require regular follow-up. These patients with active viral replication are at risk for flare of hepatitis and disease progression over time. ALT levels, liver function tests, HBV DNA and CBC should be monitored at least every six months. Patients who have experienced flares should be monitored more frequently. $\mathrm{HBeAg}$ negative patients who have persistent stable low levels of viral replication $\left(<2 \times 10^{3} \mathrm{IU} / \mathrm{mL}\right)$ can be monitored every six to 12 months. HCC surveillance should be performed on high-risk individuals every six months using abdominal ultrasound $(69,70)$.

Not all HBV-infected patients need treatment. The identification of patients at risk for cirrhosis or HBV infection complications is important so that treatment can be offered to them. The overall objective of treatment in chronic hepatitis B is to prevent the development of cirrhosis and its consequences, liver failure and HCC. The predicting factors that indicate increasing risk of cirrhosis and HCC development include the HBV DNA level, age, significant fibrosis and elevated ALT level. Of these, HBV DNA level has been most extensively studied. Several large-scale, long-term prospective studies have correlated HBV DNA level at baseline with an outcome of cirrhosis and HCC (41-43,71). Persistently elevated HBV DNA levels $>4 \log _{10} \mathrm{IU} / \mathrm{mL}$ among middle-age ( $>35$ years) male, $\mathrm{HBeAg-negative} \mathrm{Chinese} \mathrm{patients}$ have also been found to have a strong correlation with important clinical outcomes such as cirrhosis and HCC (42). This is likely the case among older $\mathrm{HBeAg}$-positive or negative patients with elevated HBV DNA levels, but probably not among young immune tolerant patients (HBeAg-positive with high HBV DNA levels). The young adults who are in the immune-tolerant phase of HBV infection or who have mild hepatitis have no or minimal liver fibrosis on biopsy $(72,73)$. Therefore, immediate treatment may not be necessary, even with elevated ALT levels. A proportion of these young adults (5\% to $10 \%$ per year) will undergo spontaneous $\mathrm{HBeAg}$ seroconversion. If at any time there is evidence of liver dysfunction or progressive hepatic fibrosis during monitoring, the treatment decision should be readdressed.

HBV DNA levels can fluctuate and the trend in levels is important. For HBeAg-positive patients, treatment should be considered if the HBV DNA is $>20,000 \mathrm{IU} / \mathrm{mL}$. HBeAg-positive patients with low levels of HBV DNA may be in the process of HBeAg seroconversion and longer monitoring is important before committing a patient to treatment. In HBeAg-negative chronic hepatitis B patients, HBV DNA levels are usually $>3 \log _{10} \mathrm{IU} / \mathrm{mL}$ to $4 \log _{10} \mathrm{IU} / \mathrm{mL}$, indicating that the patient may need treatment because this phase of infection is associated with more advanced and progressive liver disease. A liver biopsy or transient elastography testing may be necessary to guide treatment decision in $\mathrm{HBeAg}$-negative chronic hepatitis patients.

Other studies have shown a correlation between ALT level and outcome, but the association was not as strong as for HBV DNA. In particular, patients with ALT levels within the laboratory normal range were also at risk for the development of cirrhosis and HCC when the HBV DNA concentration was $>2000 \mathrm{IU} / \mathrm{mL}$. Those who have had the best prognosis have persistently very low ALT values $(<40 \mathrm{U} / \mathrm{L})$ (74). These data argue for downgrading the upper limit of normal value for ALT to $<30 \mathrm{U} / \mathrm{L}$ for men and $<19 \mathrm{U} / \mathrm{L}$ for women, especially among Asians with HBV (75). In general, any patients with an HBV DNA level $>2000 \mathrm{IU} / \mathrm{mL}$, and liver biopsy or noninvasive test showing METAVIR stage 2 or more fibrosis, should be considered for treatment. Figure 1 provides an algorithm for identifying individuals who should be considered for treatment.

HBV genotype has also been shown to be a predictor of adverse outcomes in chronic hepatitis B infection. Most studies were derived from Chinese patients and were thus limited to HBV genotypes B and C. The bulk of the evidence has shown that genotype $\mathrm{C}$ is associated 


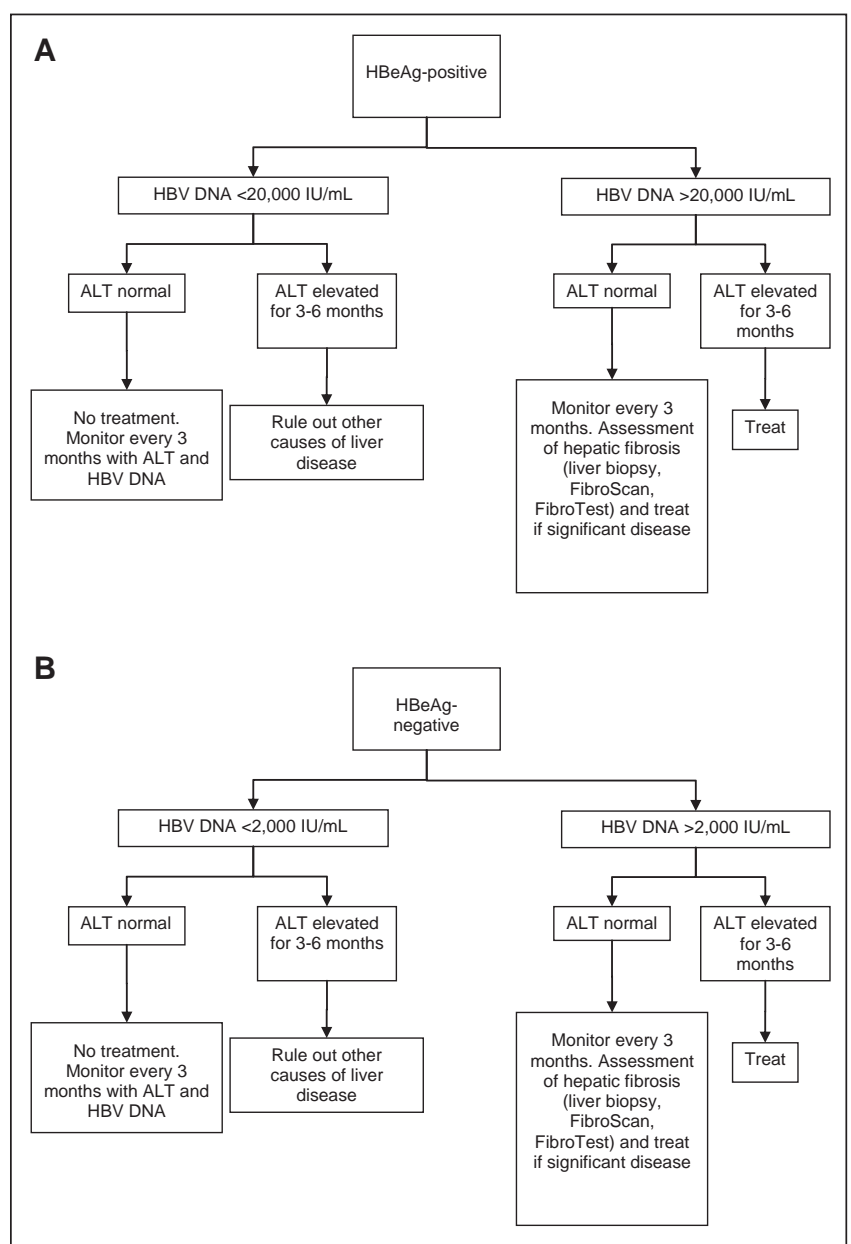

Figure 1) A Algorithm for selecting hepatitis $\mathrm{B}$ e antigen ( $\mathrm{HBeAg}$ )-positive patients for treatment. B Algorithm for selecting HBeAg-negative patients for treatment. ALT Alanine aminotransferase; HBV Hepatitis B virus

with later $\mathrm{HBeAg}$ seroconversion and more aggressive liver disease and high rate of progression to HCC (76-78). Similarly, smaller studies from Europe have indicated genotype D is associated with development of cirrhosis. On the other hand, genotype A infection among African patients is correlated with high rates of HCC (79). The HBV genotype may be important in risk prediction, because it seems to influence the natural history of chronic infection.

The treatment decision must also take into consideration the patient's health status, immune competency, age and the presence of HBV-related extrahepatic diseases. With early treatment and sustained control of HBV, complications related to infection can be avoided.

\section{Recommendations}

13. HBeAg-positive patients with HBV DNA $>20,000 \mathrm{IU} / \mathrm{mL}$ and elevated ALT $>1 \times$ upper limits of normal for three to six months should be considered for treatment. Those with significant inflammation and fibrosis on biopsy, FibroScan or Fibrotest, or abdominal ultrasound should also be treated, even if the HBV DNA is $<20,000 \mathrm{IU} / \mathrm{mL}$, or if the ALT level is normal (Class 2a, Level B).

14. HBeAg-negative patients with HBV DNA $>2000 \mathrm{IU} / \mathrm{mL}$ and elevated ALT $>1 \times$ upper limits of normal for three to six months should be considered for treatment. Patients with significant inflammation and fibrosis on biopsy, FibroScan or Fibrotest, or abdominal ultrasound should also be treated, even if the HBV DNA is $<2000 \mathrm{IU} / \mathrm{mL}$, or if the ALT level is normal (Class 2a, Level B).

\section{DRUGS TO TREAT CHRONIC HEPATITIS B INFECTION}

The goals of chronic hepatitis B treatment are to improve quality of life; to prevent or reverse liver disease progression to liver failure; to minimize the risk of HCC development; and to decrease the risk of transmission. The first-line treatment should be an agent with the highest potency and barrier to resistance. The agent will be able to reduce viremia rapidly to undetectable levels and maintain HBV DNA at undetectable levels continuously. The ability to control HBV with finite duration of treatment will also be important.

For a patient, the choice of first-line therapy should be selected according to the advantages and disadvantages of the available treatments in the setting of the patient's clinical characteristics (patient's general health, virus genotype and load) and preference. Although the efficacy of IFN is low and IFN treatment can have significant side effects, IFN treatment can be an ideal treatment for some patients whose clinical characteristics favour a good response to a fixed duration of IFN treatment. Oral nucleos(t)ides are good at suppressing HBV replication and have few side effects. These oral nucleos(t)ides do require prolonged or continuous treatment to maintain the control of HBV. Most hepatitis B patients will have clinical improvement while on oral nucleos(t)ide treatment.

Currently, there are eight approved hepatitis B treatments in Canada. In this section, information on the specific antiviral agents licensed to treat hepatitis B is provided. A summary of the efficacy of the different agents is illustrated in Figure 2 and Table 5.

\section{IFN treatment}

IFNs are cytokines, which have direct antiviral and immunomodulatory properties. Because of these properties, IFNs could be an ideal treatment for chronic hepatitis B-infected patients; however, the efficacy of interferon treatment in unselected patients is low. The HBeAg seroconversion occurs in $25 \%$ to $40 \%$ of treated patients (80-84). IFN is less effective in inducing $\mathrm{HBeAg}$ seroconversion in patients with high $\mathrm{HBV}$ DNA levels $\left(>2 \times 10^{7} \mathrm{IU} / \mathrm{mL}\right)$. The HBeAg seroconversion rates are also reduced in patients with low ALT levels $(>2 \times$ the upper limit of laboratory normal). Other predictors of poor response include male sex, age older than 40 years, cirrhosis, and HBV genotype $\mathrm{C}$ or D (67). The potential advantages of interferons over nucleos(t)ide analogues include a shorter fixed duration of therapy, the absence of resistance mutations, durable $\mathrm{HBeAg}$ seroconversion and a chance of $\mathrm{HBsAg}$ seroconversion.

In general, IFN therapy is not recommended for treatment of chronic hepatitis B patients with high viral load and low ALT due to the low response rate. Patients with hepatitis B decompensated cirrhosis should not be treated with IFN because there is a high risk of serious complications such as liver failure and sepsis. Oral nucleos(t)ide treatment should be used in decompensating hepatitis B cirrhotic patients.

The most frequently reported IFN side effects are a flu-like syndrome with symptoms of malaise, fever, fatigue, headache, myalgia and local injection site reaction. These symptoms present early during treatment and often improve over time. The psychiatric side effects of mood changes, insomnia, depression and irritability are variable in severity and often become worse as treatment continues (85).

Since the most recent CASL consensus guidelines on the management of chronic hepatitis $\mathrm{B}$, more information is available that can help select the right patients for IFN treatment and monitoring patients for response while on IFN treatment. This new information is useful to guide the use of IFN in treating $\mathrm{HBeAg}$ positive and $\mathrm{HBeAg}$ negative chronic hepatitis B patients.

\section{Treating HBeAg-positive chronic hepatitis with standard IFN or PEG IFN}

Standard IFN is given subcutaneously at a dose of 10 million IU three times per week or five million IU daily for 16 to 24 weeks (8084). With standard IFN treatment, the HBeAg seroconversion rate is approximately $30 \%$. PEG IFN alpha $2 \mathrm{a}$ and alpha $2 \mathrm{~b}$ are approved 


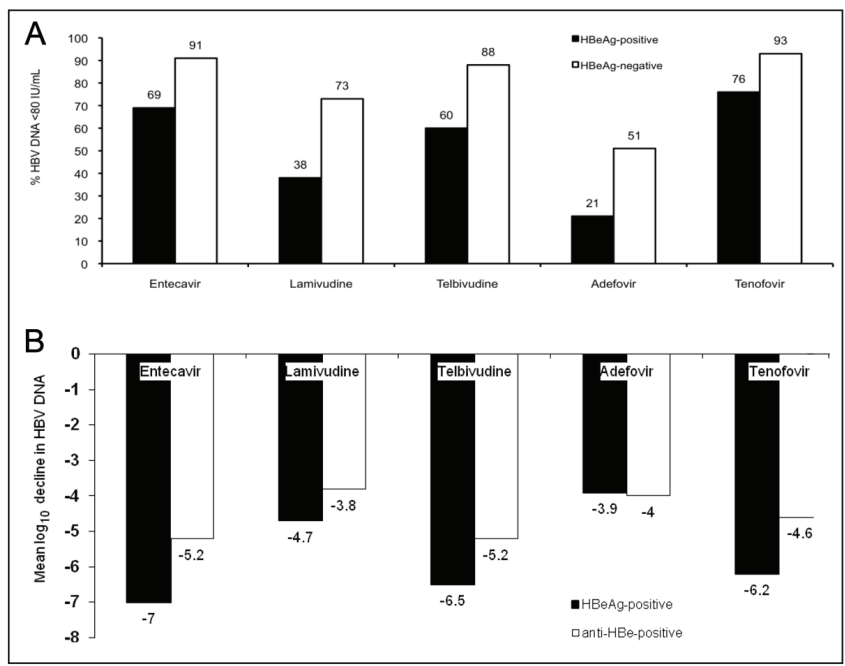

Figure 2) Relative potencies of different hepatitis B antivirals at 48 to 52 weeks of therapy. Lamivudine has been compared with entecavir (105) and telbivudine (118) in two separate, randomized, controlled trials. Tenofovir was compared with adefovir followed by open-label tenofovir in separate, randomized, clinical trials. A Proportion of patients with hepatitis $B$ virus (HBV) DNA <80 IU/mL. B Mean $\log _{10} \mathrm{IU} / \mathrm{mL}$ decline in HBV DNA levels. Anti-HBe Hepatitis B e antibody; HBeAg Hepatitis B e antigen

for the treatment of chronic hepatitis B and they can also induce $\mathrm{HBeAg}$ seroconversion in approximately $30 \%$ of the patients $(68,86,87)$. The optimal duration of PEG IFN (24 or 48 weeks) remains unclear. The addition of lamivudine to IFN-based therapies does not seem to improve overall outcome. The potential role of other nucleos $(\mathrm{t})$ ide analogues in combination with IFN-based therapies are currently being further studied. The goal of therapy (sustained virological response) is to achieve $\mathrm{HBeAg}$ seroconversion, normalization of ALT level and maintain HBV DNA level $<2000 \mathrm{IU} / \mathrm{mL}$.

The $\mathrm{HBeAg}$ seroconversion is durable in $70 \%$ to $80 \%$ of patients up to eight years of follow-up after IFN treatment (88-94). Delayed HBsAg clearance can occur in IFN-treated patients; however, this is seen in only a minority $(<10 \%)(91)$. Patients who develop HBeAg seroconversion after IFN treatment have improved survival and complication-free survival $(87,94,95)$.

Analysis of the data sets from the two largest PEG IFN trials on treatment of $\mathrm{HBeAg}$-positive chronic hepatitis has confirmed that genotype A, low viral load and high ALT are predictors of response to interferon (67). Patients with hepatitis B genotype D chronic infection do not respond to interferon treatment. A calculator has been developed to guide the selection of patients for interferon treatment (67).

During PEG IFN treatment, monitoring the decline of HBsAg and HBV DNA levels is useful to further select patients that will benefit from the full course of interferon treatment. If the HBsAg and HBV DNA levels do not decline significantly after 24 weeks of PEG IFN treatment, there is no chance of a sustained virological response and treatment can be discontinued $(96,97)$. Because HBsAg level is not a routine clinical test as this time, HBV DNA level should be checked at weeks 12, 24 and 48. Primary virological nonresponse is $<1 \log _{10}$ decrease in HBV DNA level at week 12 of therapy. Adequate virological response is defined as the decrease of HBV DNA level to $<2000 \mathrm{IU} / \mathrm{mL}$, or more than $2 \log _{10}$ decline in HBV DNA at week 24 of therapy. These definitions and monitoring can help decision making whether PEG IFN treatment should be continued.

Treating HBeAg-negative chronic hepatitis with standard IFN or PEG IFN

In $\mathrm{HBeAg}$-negative chronic hepatitis patients, the treatment response rates with standard IFN are inferior and less durable than responses achieved in HBeAg-positive patients. PEG IFN and standard IFN
TABLE 5

Hepatitis $B$ e antigen (HBeAg) seroconversion rates with hepatitis $B$ antiviral therapy

\begin{tabular}{lccc}
\hline & $\begin{array}{c}\text { Duration of } \\
\text { treatment }\end{array}$ & $\begin{array}{c}\text { HBeAg seroconversion } \\
\text { rate, \% (reference[s]) }\end{array}$ & $\begin{array}{c}\text { HBsAg } \\
\text { loss,\%* }\end{array}$ \\
\hline Standard interferon & $16-24$ weeks & $33(\mathrm{HBeAg}$ loss) (263) & $\mathrm{NA}$ \\
Pegylated interferon & $24-48$ weeks & $29-32(86,98)$ & $5-10$ \\
Lamivudine & 1 year & $17-20(111,112)$ & $\mathrm{NA}$ \\
& 3 years & $40(112)$ & \\
Adefovir & 1 year & $12(116)$ & $\mathrm{NA}$ \\
& 3 years & 43 & \\
Entecavir & 1 year & $21(105)$ & 0 \\
& 3 years & $39(136)$ & 3 \\
Telbivudine & 1 year & $22(118)$ & 0 \\
& 2 years & $33(119)$ & $\mathrm{NA}$ \\
Tenofovir & 1 year & $21(100)$ & 3 \\
& 5 years & $49(101)$ & 11 \\
\hline
\end{tabular}

*Hepatitis B surface antigen (HBsAg) seroconversion rates by the end of follow-up (the duration of follow-up was not the same in all studies). NA Not applicable

treatments in $\mathrm{HBeAg}$-negative chronic hepatitis patients have not been compared directly. However, a weekly injection program is preferable to daily or thrice weekly injections when the cost of treatment is equivalent. $\mathrm{HBe} \mathrm{Ag}$ seroconversion cannot be an end point of treatment. Normalization of ALT levels and viral suppression of HBV DNA level to $<2000 \mathrm{IU} / \mathrm{mL}$ becomes the end point of treatment. With PEG IFN alpha 2a given for 48 weeks, the treatment is effective in suppressing HBV DNA to $<20,000$ copies/mL (approximately $4000 \mathrm{IU} / \mathrm{mL}$ ) in $43 \%$ of patients (98). The addition of lamivudine to PEG IFN alpha 2a did not improve the viral suppression rate. The durable response rate with undetectable HBV DNA at week 24 posttherapy is $<20 \%$. A small number of treatment-responded patients have lost the HBsAg. In a follow-up study of these patients three years later, $28 \%$ of PEG IFN-treated patients have HBV DNA levels $<2000 \mathrm{IU} / \mathrm{mL}$, indicating that the response can be durable (99). The data do support the use of PEG IFN to treat HBeAg-negative chronic hepatitis.

HBsAg monitoring has been proposed as a tool to monitor PEG IFN treatment response in $\mathrm{HBeAg-negative} \mathrm{chronic} \mathrm{hepatitis} \mathrm{B}$ patients. In one study (62), the HBsAg level decline of $>0.5 \log _{10} \mathrm{IU} / \mathrm{mL}$ at week 12 treatment or $1 \log _{10} \mathrm{IU} / \mathrm{mL}$ at week 24 treatment is a good predictor of sustained treatment response and this tool has good positive and negative predictive values. In another study (61), an on-treatment $\mathrm{HBsAg}$ decline $>1 \log _{10} \mathrm{IU} / \mathrm{mL}$ and a week $48 \mathrm{HBsAg}$ level $<100 \mathrm{IU} / \mathrm{mL}$ are associated with sustained HBV DNA suppression. A week $48 \mathrm{HBsAg}$ level $<10 \mathrm{IU} / \mathrm{mL}$ is associated with $\mathrm{HBs} A g$ clearance three years posttherapy (61). It is not yet clear whether a 'stopping rule' can be established at this time. The combined use of HBsAg and HBV DNA level monitoring may offer the solution. The absence of a decrease in $\mathrm{HBsAg}$ or a $<2 \log _{10}$ copies/mL decline of HBV DNA at week 12 treatment seems to have a strong negative predictive value of a sustained virological response (62). Patients with neither HBsAg level decline nor more than $2 \log _{10}$ HBV DNA decline at week 12 treatment will not have a sustained virological response and interferon treatment can be discontinued.

\section{Recommendation}

15. The consensus guideline committee has recommended that PEG IFN remain one of the first-line treatments for chronic hepatitis B (Class 2a, Level A).

Oral drugs to treat hepatitis B and their use

In the following section, information on the specific antiviral agents licensed to treat hepatitis B is provided. Various patterns of response on antiviral therapy are defined in Table 6. A comparison of the 


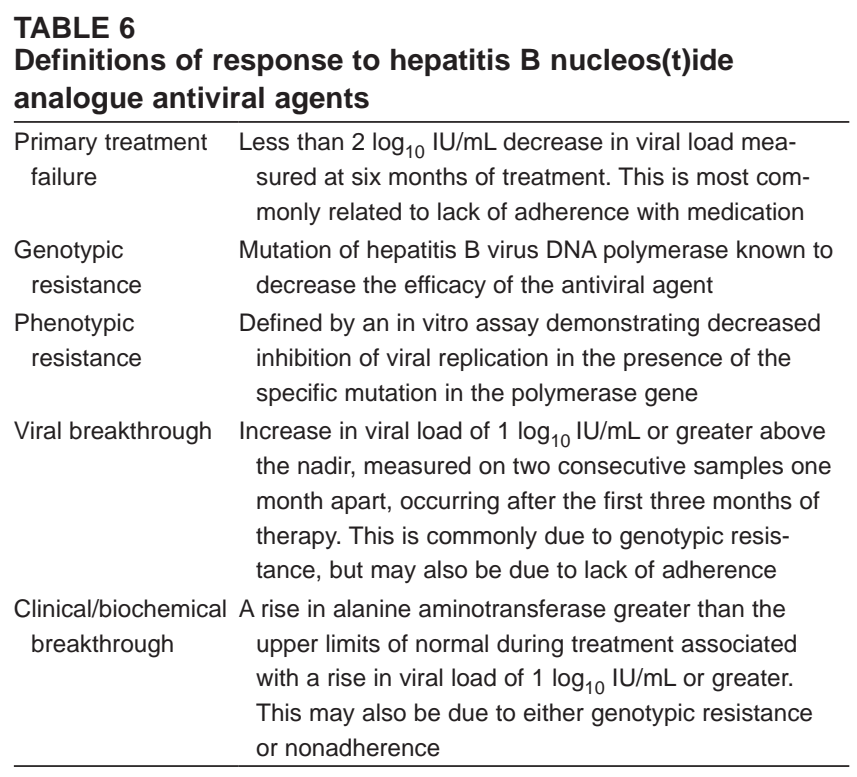

relative potency of the different oral antiviral agents in non head-tohead clinical trials is illustrated in Table 5 and Figure 2.

Tenofovir (Viread, Gilead Sciences Inc, USA): Tenofovir disoproxil fumarate (tenofovir) is the latest oral antiviral approved for chronic HBV infection. Tenofovir is a purine nucleotide reverse transcriptase inhibitor that has shown efficacy in treatment-naïve HBeAg-positive and HBeAg-negative chronic hepatitis B (100). It is licensed for HIV infection, but it also has potent anti-HBV activity. Ongoing large phase 3 studies reported that HBV DNA suppression $<169 \mathrm{IU} / \mathrm{mL}$ was achieved in $76 \%$ and $93 \%$ of $\mathrm{HBeAg}$-positive and negative patients after one year of therapy, respectively. Normalization of ALT occurred in two-thirds of patients. HBeAg seroconversion was reported in $25 \%$ (year 1) and 49\% (year 5) of HBeAg-positive patients. At the end of five years of treatment, $87 \%$ of patients overall experienced improvement in liver histology, defined as a $>2$ point improvement on the Knodell score. Of the patients with cirrhosis at baseline, $75 \%$ had at least a two-point reduction in Ishak score after long-term tenofovir therapy (101). Nephrotoxicity and hypophosphatemia with long-term therapy were uncommon, $1.2 \%$ and $0.9 \%$ of patients, respectively. Importantly, no confirmed cases of antiviral resistant mutation to tenofovir have been documented after five years of treatment (102). Interestingly, $\mathrm{HBs} \mathrm{Ag}$ loss occurred in $11 \%$ of patients during the same period (101). An analysis of the Asian subset showed similar efficacy compared with Caucasians. Predictors of HBsAg loss included decline in HBsAg levels on treatment, HBV genotype A and shorter duration of chronic infection (less than four years). Tenofovir is also a drug of choice in HBV/HIV coinfection as part of highly active antiretroviral therapy (HAART) (see section on HIV/HBV coinfection below).

$\mathrm{HBeAg}$-positive patients: In a study of 266 patients randomly assigned to receive adefovir $10 \mathrm{mg}$ daily versus tenofovir $300 \mathrm{mg}$ daily for one year, $75 \%$ of patients who received tenofovir had undetectable HBV DNA compared with only $13 \%$ of patients in the adefovir group (100). Normalization of ALT, histological improvement, and HBeAg seroconversion occurred in $68 \%$ versus $54 \%, 74 \%$ versus $68 \%$ and $21 \%$ versus $18 \%$ of tenofovir versus adefovir patients, respectively. After 48 weeks, all patients received open-label tenofovir. During the second year of treatment, those who had received adefovir rapidly caught up to the tenofovir group, with similar proportions of patients achieving HBV DNA undetectability (78\% and $78 \%$ ), HBeAg seroconversion (26\% and 24\%) and even HBsAg loss (4\% and 5\%). Virological and biochemical responses were maintained with up to five years of continuous treatment; $\mathrm{HBeAg}$ loss and seroconversion progressively increased with duration of tenofovir (49\% and 40\%, respectively) (101).
HBeAg-negative patients: In another randomized study, $375 \mathrm{HBeAg}$ negative patients were randomly assigned to receive adefovir or tenofovir. Similar to the HBeAg-positive trial, a significantly higher proportion of patients receiving tenofovir achieved undetectable HBV DNA levels compared with patients receiving adefovir (93\% versus $63 \%$, respectively). However, ALT normalization ( $76 \%$ to $77 \%$ ) and histological improvement (69\% to $72 \%$ ) were similar between the two groups. During open-label tenofovir from year 2 onwards, almost all patients achieved undetectable HBV DNA (100).

Lamiundine-resistance: Tenofovir also appears to be effective for the treatment of lamivudine-resistant HBV patients. Although phase 3 randomized trials using tenofovir or tenofovir plus emtricitabine (Truvada, Gilead Sciences, USA) are ongoing, retrospective studies of tenofovir with or without ongoing lamivudine have reported high rates of viral suppression in patients with documented $\mathrm{rtL180M} \pm$ rtM204V/I mutation $(102,103)$. It remains unclear whether ongoing lamivudine needs to be continued in these patients, but a brief period of overlap (six months) with lamivudine is reasonable. These studies have led to rapid adoption of tenofovir as the treatment of choice for lamivudine-resistant HBV.

Adefovir resistance: Clinical data on the use of tenofovir for treatment of patients with adefovir-resistant HBV are lacking. Tenofovir appears to have reduced efficacy in patients with documented adefovir-resistant mutation (rtN236T) due to partial cross-resistance (104). In this situation, combination tenofovir plus emtricitabine may be more effective. In those with rtA $181 \mathrm{~V}$, the response to tenofovir appears to be preserved, suggesting that confirmation of specific antiviral-resistant mutations is important before institution of salvage therapy.

Entecavir (Baraclude, Bristol-Myers Squibb, USA): Entecavir is a selective guanosine analogue and a potent inhibitor of HBV DNA replication. It has been shown to be more effective than lamivudine in terms of viral suppression in treatment-naïve patients (105). Entecavir was well tolerated and had a similar side effect profile to lamivudine in large clinical trials. In treatment-naive patients, $\mathrm{HBeAg}$ seroconversion at one year is similar to other nucleoside analogues at $21 \%$ after year 1 and $39 \%$ after year 3 (Table 5) (105). Only 1\% to 2\% of subjects developed resistance to entecavir after five years (106). However, this is in contradistinction to those with previous lamivudine resistance, who develop entecavir resistance at high rates after one year of entecavir (8\%). Resistance to entecavir requires the presence of the YMDD mutations that confer resistance to lamivudine, and also requires the presence of one of two or three additional mutations (107). These additional mutations in isolation do not confer resistance to entecavir. Therefore, pre-existing lamivudine-resistant entecavir-treated patients are at risk of developing resistance to entecavir (106). For this reason, entecavir should not be used to rescue patients with lamivudine-resistant HBV. $\mathrm{HBeAg}$-positive patients: In a large phase III study, 715 patients were randomly assigned to entecavir $0.5 \mathrm{mg}$ versus lamivudine $100 \mathrm{mg}$. Entecavir-treated patients had higher rates of HBV DNA undetectability (67\% versus $36 \%)$ and histological improvement (72\% versus $62 \%$ ) compared with the lamivudine group. However, HBeAg seroconversion rates were comparable between the groups (11\% to $12 \%$ ) after one year of treatment (108).

HBeAg-negative patients: In another phase III study of 648 patients (109), in which entecavir was compared with lamivudine, virological suppression and histological improvement were significantly higher in entecavir-treated patients $(90 \%$ versus $72 \%$ and $70 \%$ versus $61 \%$, respectively) (109).

Lamivudine-refractory patients: Two hundred eighty-six HBeAg-positive patients with persistent viremia on lamivudine were treated with highdose entecavir ( $1 \mathrm{mg}$ daily). Only 20\% of patients achieved undetectable HBV DNA after one year of treatment, and $8 \%$ of patients subsequently developed resistance to entecavir, and this rate increased substantially with prolonged duration of therapy (110). Thus, entecavir is not recommended as salvage therapy for lamivudine-resistant HBV.

Lamivudine (Heptovir, GlaxoSmithKline, United Kingdom): Lamivudine is a pyrimidine nucleoside analogue inhibitor of the HBV 
polymerase. It was the first oral agent approved for the treatment of HBV in Canada and until 2006 was the only such agent available. Thus, many HBV patients may have received lamivudine in the past and many patients who have recently immigrated from southeast Asia have been exposed to lamivudine, where the drug is still widely used. Generally, lamivudine is effective at reducing HBV DNA levels and has established long-term safety (111). The relative potency of lamivudine compared with other antivirals is reported in Figure 2. However, the major disadvantage of lamivudine is the very high risk of developing antiviral resistance, approaching $70 \%$ at four years (112). Furthermore, the development of lamivudine resistance may lead to cross-resistance to other agents such as entecavir and telbivudine and limit future treatment options. Therefore, lamivudine is no longer a suitable first-line treatment for hepatitis B, but may still have a limited role in certain situations in which time-limited therapy is indicated such as treatment of immune tolerant pregnant HBV carriers, or as prophylaxis for those undergoing short-term immunosuppression.

Lamivudine was shown to reduce progression of liver disease and possibly hepatoma in HBV cirrhotic patients compared with placebo in a randomized study $(113,114)$. The benefit of treatment was diminished in those who developed lamivudine resistance and virological breakthrough, indicating the importance of viral suppression and avoidance of resistance. Other agents that induce potent viral suppression have also been shown to improve long-term outcomes (113).

Adefovir (Hepsera, Gilead Sciences Inc, USA): Adefovir dipivoxil is a nucleotide analogue. Adefovir is a less potent agent and does not achieve complete viral suppression in the majority of patients within the first year, possibly due to the low approved daily dose $(10 \mathrm{mg})$. Risk factors for adefovir resistance are high baseline viral load and inadequate suppression of virus on therapy $(115,116)$. Side effects of adefovir include nephrotoxicity, hypophosphatemia and, rarely, Fanconi syndrome. Therefore, renal function (estimated glomerular filtration rate) should be monitored at baseline and every three months during therapy. Adefovir add-on therapy is useful in patients with lamivudine resistance (117), although tenofovir has become the treatment of choice in this situation.

Telbivudine (Sebivo, Novartis, Switzerland): Telbivudine is a beta L-nucleoside analogue with relatively potent antiviral efficacy against HBV. Telbivudine was more effective than lamivudine in treatmentnaive $\mathrm{HBeAg}$-positive and $\mathrm{HBeAg}$-negative chronic hepatitis $\mathrm{B}$ (118). However, genotypic resistance rates of $5 \%$ and $11 \%$ were reported after one and two years of telbivudine, respectively $(118,119)$. Asymptomatic rises in creatine kinase and symptomatic myositis occurred in approximately $12 \%$ of patients. Due to these disadvantages, telbivudine is not considered first-line therapy for chronic hepatitis B in North America. However, the drug is available in many Asian countries and recent immigrants may have been exposed to telbivudine.

Telbivudine may have a limited role for short-term treatment of the pregnant HBV carrier with high viral load, because it is classified as Food and Drug Administration (FDA) class B in pregnancy. In a recent study of 229 pregnant HBV carriers in China, telbivudine given in the second or third trimester of pregnancy was effective in suppressing HBV DNA levels and reducing the risk of perinatal transmission of $\mathrm{HBV}(0 \%$ versus $8 \% \mathrm{HBs} \mathrm{Ag}$-positive in telbivudine versus placebo infants with seven months' postpartum follow-up (120).

Emtricitabine (Emtriva, Gilead Sciences Inc, USA): Emtricitabine (FTC) is a pyrimidine nucleoside analogue, with a spectrum of activity and resistance profile that is very similar to lamivudine (3TC) $(121,122)$. Although it is licensed for use in combination with tenofovir (Truvada, Gilead Sciences Inc, USA) in Canada for HIV, it is not licensed for use as monotherapy in HBV infection.

De novo combination therapy: Although combination therapy for hepatitis B may be appropriate in certain patient populations, there remain little data to support routine use in treatment-naïve patients. In a single-centre study, in which combination lamivudine plus adefovir was compared with lamivudine alone, no difference in HBV DNA suppression, $\mathrm{HBe} A g$ seroconversion or ALT normalization was observed (123). However, resistance to lamivudine was significantly lower in the combination group compared with the monotherapy group. On the other hand, combination lamivudine plus telbivudine was less effective than telbivudine alone for all end points (124), possibly due to antiviral antagonism. In a randomized open-label study of entecavir plus tenofovir versus entecavir alone (125), combination therapy was not more effective in reducing HBV DNA levels or in inducing $\mathrm{HBeAg}$ seroconversion overall. However, in the subset of patients with baseline HBV DNA $>8 \log _{10} \mathrm{IU} / \mathrm{mL}$, combination therapy was more effective in reducing HBV DNA $<50 \mathrm{IU} / \mathrm{mL}$ (79\% versus $62 \%, P=0.04)(125)$. In cirrhotic patients, particularly those with hepatic decompensation, the development of resistance to antiviral agents may lead to fatal flares of liver disease. Therefore, combination therapy can be considered in this setting (126). Suggested regimens include lamivudine plus tenofovir, tenofovir plus emtricitabine or tenofovir plus entecavir.

\section{Recommendations}

16. Tenofovir or entecavir is first-line therapy for treatment-naive HBV patients because they are the most potent agents available with no (tenofovir) or very low (entecavir) rates of antiviral resistance (Class 1, Level A).

17. Tenofovir is first-line therapy for lamivudine-resistant HBV. Entecavir should not be used in this setting due to the risk of development of entecavir resistance (Class 1, Level A).

\section{On-treatment monitoring - nucleos $(\mathrm{t})$ ide therapy}

Patients treated with nucleos $(\mathrm{t})$ ide analogues should be monitored with HBV DNA and ALT initially every three months on treatment, and every six months once aviremia is achieved. This is to confirm an initial fall in HBV DNA level, and in the case of lamivudine, telbivudine and adefovir, to determine whether treatment with the same drug can be maintained, or whether another drug should be added or substituted (127). HBV DNA levels must be monitored regularly to allow for early detection of viral breakthrough leading to resistance. Patients on nucleotide agents require monitoring of renal function and serum phosphate levels every three to six months. Patients receiving telbivudine require monitoring of creatine kinase levels. Patients must continue to be screened for $\mathrm{HCC}$ as per current guidelines (Table 7), irrespective of response to antiviral treatment.

The traditional end point of oral antiviral therapy for HBeAgpositive patients is $\mathrm{HBeAg}$ seroconversion. The probability of $\mathrm{HBeAg}$ seroconversion is similar across the various agents (approximately 20\% in year 1) and increases to $40 \%$ to $50 \%$ after five years of continuous therapy. An additional 12 months of consolidation therapy following $\mathrm{HBeAg}$ seroconversion is recommended to reduce the risk of virological relapse following seroconversion. The durability of oral therapy is approximately $75 \%$. Ongoing treatment is recommended for those patients who have not yet achieved HBeAg seroconversion.

For HBeAg-negative patients, the duration of therapy is somewhat undefined. Predictors of a durable response have been difficult to identify in clinical studies. Therefore, the majority of these patients will require long-term therapy. The ultimate, yet difficult-to-achieve end point, in this category of patients is $\mathrm{HBsAg}$ loss or seroconversion. $\mathrm{HBs} A g$ loss was reported in $12 \%$ and $<1 \%$ of $\mathrm{HBeAg}$-positive and $\mathrm{HBeAg}$-negative patients receiving continuous tenofovir therapy, respectively.

\section{Recommendations}

18. The target HBV DNA level on oral antiviral therapy is undetectable. This should be measured using the most sensitive test available, ie, currently, real-time polymerase chain reaction (PCR) ('Taqman') assay. Assays of lower sensitivity are not recommended (Class 2, Level A). 


\section{TABLE 7}

Hepatitis B carriers who should undergo regular screening for hepatocellular carcinoma

All patients with cirrhosis

Other hepatitis B-infected individuals

- Africans $>20$ years of age

- Asian men $>40$ years of age

- Asian women $>50$ years of age

- Patients with family history of hepatoma

- Patients with active inflammation on liver biopsy

- Patients awaiting liver transplantation

- HIV coinfected

19. In HBeAg-positive patients, nucleos(t)ide analogue therapy should be continued until 12 months after $\mathrm{HBeAg}$ seroconversion (consolidation therapy) to maximize the durability of the response (Class 2a, Level B).

20. In HBeAg-negative patients, nucleos(t)ide analogue therapy should be continued indefinitely or until HBsAg loss or seroconversion occurs (Class 2a, Level B).

21. Patients must continue to be screened for HCC as per current guidelines (see Table 2), irrespective of response to antiviral treatment (Class 2, Level B).

\section{HBV antiviral resistance testing}

Mutations that confer resistance to antiviral agents may occur spontaneously and are not caused by the antiviral agents. Most resistant mutants have diminished replication competence and do not survive. However, in the presence of a selective pressure that inhibits the growth of wild-type virus, proliferation of some mutant virus species occurs until they come to be the dominant species. Depending on replication competence, mutants can replicate at high levels over time. Clinically, antiviral resistance is suspected when serial HBV DNA testing shows increases in viral load of more than 10-fold (1 $\log _{10} \mathrm{IU} / \mathrm{mL}$ ) compared with nadir (128). Thus, monitoring for antiviral resistance requires regular assessment of HBV DNA concentrations. When resistance develops, particularly to lamivudine, secondary mutations may occur that may reduce susceptibility to other antivirals (129). Genotypic resistance can be detected by various methods, such as population sequencing, reverse hybridization, clonal analysis and ultra-deep sequencing methods. Sequencing requires that the mutant virus be present in at least $20 \%$ to $25 \%$ of the viral population. Reverse hybridization (line probe assay) is more sensitive in detecting mutants at a lower level (5\% total viral population) (130). A working knowledge of common HBV polymerase mutations is necessary, due to the cross-resistance, which will limit future treatment options.

The development of resistance to antiviral therapy is not benign. There is considerable evidence that the benefits of viral suppression are lost (131). Acute flares of hepatitis related to lamivudine- or adefovirresistant HBV can occur, and this may be fatal, particularly in cirrhotic patients. The development of resistance is a strong indication to change therapy. It is not acceptable for patients with lamivudine resistance to continue to be treated with lamivudine monotherapy when effective alternatives exist.

All nucleos(t)ide analogues are associated with the development of resistance. The rate at which antiviral resistance to individual agents develops has not been accurately defined, because long-term studies are lacking and resistance was evaluated only in small subgroups of patients that were initially recruited into trials. Nonetheless, rates of antiviral resistance from non-head-to-head studies for various agents are compared in Figure 3.

Specific antiviral-resistant mutations in the HBV polymerase gene that are associated with resistance to various agents are shown in Table 8 (132). Risk factors for antiviral resistance were determined mainly from studies of lamivudine, due to the high rate of resistance. These

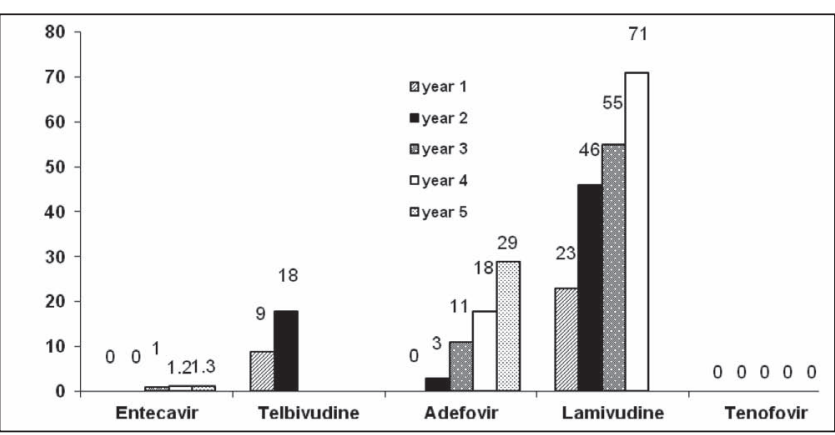

Figure 3) Rates of resistance to antiviral agents by duration of therapy

\section{TABLE 8}

Mutations conferring resistance to hepatitis B nucleos(t)ide antivirals

\begin{tabular}{lcccc}
\hline & \multicolumn{4}{c}{ Domain } \\
\cline { 2 - 5 } Agent & A & B & C & D \\
\hline Lamivudine & L80V/I & V173L, & M204V/I/S & \\
& & L180M & & \\
Adefovir & A181V/T & & N236T \\
Entecavir & & S202I & M250V \\
Telbivudine & I169T, T184G & S204I & \\
Tenofovir $^{\ddagger}$ & & M201 & \\
\hline
\end{tabular}

*The number refers to the amino acid position. The letters before the numbers represents the wild type amino acid. The letters after the number represents the substituted amino acid; ${ }^{\dagger}$ The entecavir mutations only confer resistance in the presence of the M204V, M204I and the L180M mutations. In the absence of these additional mutations the entecavir mutations do not cause resistance; ${ }^{\ddagger}$ After five years of continuous tenofovir therapy, there are no confirmed reports of tenofovir-resistant hepatitis $B$ virus polymerase mutation

included high baseline HBV DNA, lack of virological response after six months of treatment, and prolonged duration of therapy and prior antiviral resistance. In a trial of telbivudine versus lamivudine, those who failed to achieve undetectable HBV DNA at six months of telbivudine were at risk of telbivudine resistance at one and two years and were less likely to achieve HBeAg seroconversion (133). Thus, switching to more potent therapy is recommended in those who fail to achieve a virological response after six months of medium potency therapy such as lamivudine or telbivudine (127).

Early detection of antiviral resistance is important to avoid ALT flares and decompensation of liver disease. In a study of 74 patients with lamivudine resistance, early institution of adefovir add-on therapy when HBV DNA was $<6 \log _{10}$ copies/mL was associated with higher rates of HBV DNA resuppression and lower rate of ALT flares, compared with the group in which HBV DNA was $>6 \log _{10}$ copies $/ \mathrm{mL}$ (117). Therefore, treatment is more likely to be effective if a new agent is introduced when the viral load is low than when it is high. To detect early virological breakthrough, HBV DNA levels should be monitored every three to six months depending on the agent used. Antiviral resistance testing is recommended in those with confirmed virological breakthrough to differentiate true antiviral resistance from medication nonadherence.

Primary nonresponse is defined as a $<1 \log _{10}$ reduction in HBV DNA at week 12 or $<2 \log _{10}$ reduction in HBV DNA at 24 weeks of antiviral therapy (127). Antiviral testing is recommended to rule out resistance, which may predate the start of treatment. Medication adherence should be questioned and counselling for those found to be nonadherent. Occasionally, there may be problems with absorption, medication dose or other pharmacological reasons for nonresponse, but these are poorly defined and difficult to confirm.

For those receiving therapy with less-potent agents such as lamivudine or adefovir, treatment can be switched to a more potent agent such as tenofovir or entecavir (in the absence of lamivudine resistance) at 24 weeks, and HBV DNA repeated in three months. Primary 
nonresponse is extremely uncommon in those receiving tenofovir or entecavir as first-line therapy.

\section{Recommendations}

22. Antiviral resistance testing should be used to differentiate between nonadherence and emergence of resistant virus in patients with virological breakthrough or persistent viremia, if available. Confirmation of antiviral resistance mutations should be performed before salvage therapy is introduced (Class 2 , Level C).

23. HBV DNA should be monitored every three months initially to allow early detection of antiviral resistance, and every six months once aviremia is achieved (Class 2, Level B).

\section{Management of resistance to specific antiviral drugs}

Resistance to lamivudine: Previous studies demonstrated that addition of adefovir after virological breakthrough, but before clinical breakthrough (ie, when the viral load is still low), is one option (117). Switching to adefovir monotherapy is associated with a high rate of adefovir resistance (20\% after one year) and is not recommended $(131,134,135)$. However, more recent restrospective studies have shown tenofovir monotherapy is also effective as salvage therapy for lamivudine resistance $(103,104)$. Rapid HBV DNA suppression occurs in most patients and there were no reports of tenofovir resistance among lamivudine-resistant HBV patients. Phase III studies of tenofovir compared with tenofovir/emtricitabine for lamivudine-resistant HBV are still under way. Entecavir is not an acceptable choice for lamivudine resistance because the response to entecavir is reduced and the risk of entecavir resistance is high (32\% after three years) (136). Lamivudineresistant HBV is cross-resistant to telbivudine and also to emtricitabine. Table 9 illustrates the relative activity of specific antiviral agents in the setting of antiviral drug resistance.

\section{Recommendation}

24. The treatment of choice for lamivudine-resistant HBV infection is tenofovir (Class 2, Level A).

Resistance to adefovir: Genotypic resistance to adefovir monotherapy is rare in the first one to two years of therapy but progressively increases to approximately $29 \%$ of patients after five years of continuous therapy (137). Virological breakthrough on adefovir has been associated with adverse clinical outcomes such as decompensation of liver disease (130). Lamivudine, telbivudine or entecavir are all acceptable choices for salvage therapy. However, there are no large studies confirming the efficacy of these agents, but in vitro data support their use. Tenofovir is also believed to be effective in adefovir-resistant HBV, but there are reports of reduced efficacy of tenofovir in the setting of rtN236T mutation, which reduces its susceptibility (104). Thus, confirmation of specific mutations to adefovir is important before switching antiviral therapy.

Resistance to entecavir: Entecavir has a very high genetic barrier to resistance. Entecavir resistance requires a lamivudine-resistant backbone (YMDD mutation). YMDD mutation alone decreases entecavir potency, but is not enough to produce resistance. Nonetheless, the presence of rtM204V and rtL180M, and one or more additional mutations (rt169T, rtT184G, rtS202I, rtM250V), is able to confer resistance to entecavir (138). However, in the absence of the rtM204V and $\mathrm{rtL} 180 \mathrm{M}$ mutations these additional mutations are not associated with any decrease in potency. In the registration studies of entecavir in lamivudine-resistant patients, entecavir-resistant mutations were detected in a proportion of patients at baseline before the introduction of entecavir (138). As a result, genotypic resistance was identified in $7 \%$ and viral breakthrough in $1.6 \%$ patients at the end of the first year of therapy (138). This increased to more than $30 \%$ at the end of the third year of therapy. By contrast, in nucleoside-naïve subjects, resistance to entecavir occurred in approximately only $1 \%$ to $2 \%$ of patients after three years (107). Entecavir resistance can be treated with either adefovir or tenofovir (based on in vitro data only).
TABLE 9

Relative activity of hepatitis B antivirals in the presence of pre-existing mutations in the polymerase gene

\begin{tabular}{|c|c|c|c|}
\hline \multicolumn{4}{|c|}{ Resistance mutation } \\
\hline $\begin{array}{c}\text { Lamivudine } \\
\text { resistant }\end{array}$ & $\begin{array}{l}\text { Adefovir } \\
\text { resistant }\end{array}$ & $\begin{array}{l}\text { Adefovir } \\
\text { resistant }\end{array}$ & $\begin{array}{l}\text { Entecavir } \\
\text { resistant }\end{array}$ \\
\hline $\begin{array}{l}\text { L180M + } \\
\text { M204V, M204I }\end{array}$ & N236T & A181V & $\begin{array}{l}\text { L180M + } \\
\text { M204V/I + } \\
\text { I169T +/- } \\
\text { T184G +/- } \\
\text { S202I +/- } \\
\text { M250V }\end{array}$ \\
\hline $\begin{array}{l}\text { Lamivudine, } \\
\text { entecavir, } \\
\text { telbivudine }\end{array}$ & $\begin{array}{l}\text { Adefovir, } \\
\text { tenofovir }\end{array}$ & $\begin{array}{l}\text { Adefovir, } \\
\text { lamivudine }\end{array}$ & $\begin{array}{l}\text { Entecavir, } \\
\text { lamivudine, } \\
\text { telbivudine }\end{array}$ \\
\hline $\begin{array}{l}\text { Adefovir, } \\
\text { tenofovir }\end{array}$ & $\begin{array}{c}\text { Lamivudine, } \\
\text { entecavir, } \\
\text { telbivudine }\end{array}$ & $\begin{array}{l}\text { Tenofovir, } \\
\text { entecavir }\end{array}$ & $\begin{array}{l}\text { Adefovir, } \\
\text { tenofovir }\end{array}$ \\
\hline
\end{tabular}

- Negative; + Positive

Resistance to telbivudine: Little is known about treatment of resistance to telbivudine, which occurs in $18 \%$ of patients at the end of two years of therapy (124). Resistance is mainly mediated by the rtM204I mutation and uncommonly by other mutations. Therefore, crossresistance with lamivudine and emtricitabine can be expected. Adefovir and tenofovir may be used for telbivudine-resistant HBV, but entecavir should be avoided as in the case of lamivudine resistance.

Resistance to tenofovir: Tenofovir has a very high genetic barrier to resistance. To date, there have been no confirmed cases of tenofovir resistance in HBV monoinfected patients after three to five years of continuous therapy (102). In fact, there is no known signature mutation for tenofovir in the HBV polymerase gene. A case report documented rtA194T substitution in an HIV/HBV coinfected patient (139), but this mutation has not been reported in HBV monoinfected patients and is likely not clinically significant. In registration trials of tenofovir, among $4 \%$ of patients who did not achieve undetectable HBV DNA, population sequencing to detect resistance revealed no conserved site changes, although resistance surveillance is ongoing.

\section{Post-treatment and long-term off-treatment monitoring}

Elevated HBV DNA levels have been shown to predict flares of viral hepatitis. Because the vast majority of patients are asymptomatic even during flares, attention to regularly scheduled blood work and abdominal ultrasound is necessary. Although each individual flare may be short lived and not significant on its own, cumulative necroinflammation and fibrosis develop with repeated flares of disease. Because the period of ALT elevation may be brief, frequent testing is necessary. Monitoring should include HBV DNA, HBsAg and HBeAg, ALT, liver enzymes, tests of liver function and CBC.

\section{Hepatoma screening}

The annual incidence of hepatoma in HBV-infected individuals without cirrhosis is $0.4 \%$ to $0.6 \%$ in Asians, $0.2 \%$ in Alaskan natives and approximately $0.3 \%$ in Caucasians (140-143). There are insufficient data on the incidence of HCC in Africans or North American blacks. In cirrhosis, the incidence of HCC development is $>2 \%$ per year, with a cumulative five-year incidence from $15 \%$ to $20 \%$ (69). Not all patients with hepatitis B are at equal risk of developing HCC. Known risk factors for hepatoma include male sex, family history, high-level viral replication, elevated ALT levels, HBeAg-positive status, HBV genotype $\mathrm{C}$, hepatitis $\mathrm{C}$ and/ or hepatitis $\mathrm{D}$ and/or HIV coinfection, and concomitant liver disease such as alcoholic liver disease and nonalcoholic fatty liver. A nomogram based on the Risk Evaluation of Viral Load Elevation and Associated Liver Disease/Cancer-Hepatitis B Virus (REVEAL-HBV) database was recently published and incorporates all of the above risk factors to allow for risk stratification (144). Another 


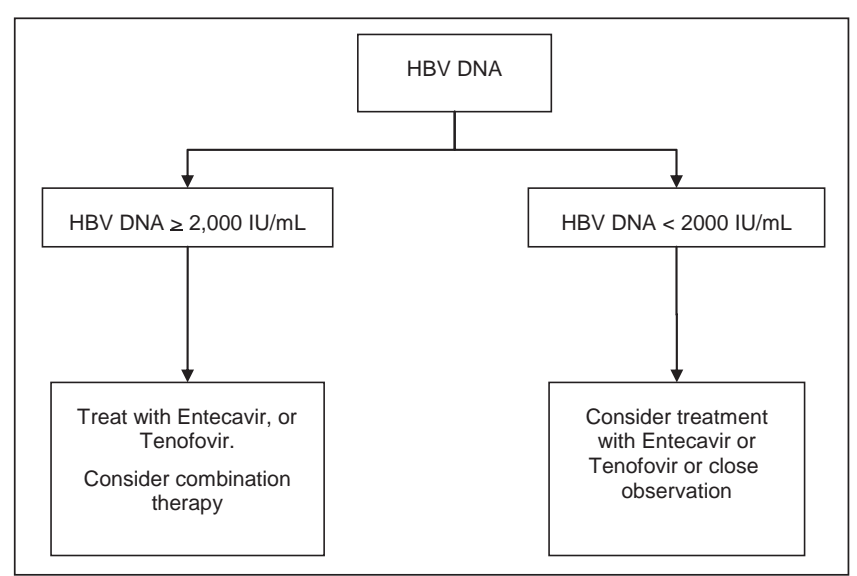

Figure 4) Suggested algorithms for management of patients with compensated hepatitis B cirrhosis. HBV Hepatitis B virus

model for prediction of HCC has been developed and validated in cohorts of Chinese patients (145).

Surveillance should be performed every six months using abdominal ultrasound in those deemed to be at high risk for hepatoma (69). Alpha-fetoprotein testing is not an effective screening method (146), and is not recommended as a screening modality for HCC.

The categories of patient who should be screened are presented in Table 7 .

\section{Recommendation:}

25. Abdominal ultrasound screening every six months is recommended in the following patients with chronic HBV infection (Class 2, Level B)

a. Asian men $>40$ years of age

b. Asian women $>50$ years of age

c. African-Canadian patients $>20$ years of age

d. All patients with cirrhosis irrespective of age

e. All patients with a family history of HCC

f. All HIV coinfected patients

Management of hepatitis B cirrhosis

All patients with well-compensated cirrhosis should be considered for therapy if the HBV DNA level is $>2000 \mathrm{IU} / \mathrm{mL}$ whether they are $\mathrm{HBeAg}$ or anti-HBe positive (114). If the HBV DNA is lower than this threshold, patients may be observed closely with measurements of HBV DNA and ALT every three to six months or they may be considered for therapy. Standard interferon or PEG IFN may be used with caution in these patients, but nucleos(t)ide analogues are preferred. Nucleos(t)ide analogue treatment should continue indefinitely in patients with cirrhosis, even if such patients undergo $\mathrm{HBeAg}$ seroconversion. A suggested algorithm for the management of hepatitis B cirrhosis is shown in Figure 4.

\section{Hepatic decompensation}

All patients with hepatic decompensation due to hepatitis B should be treated with nucleos(t)ide analogues - regardless of HBV DNA concentration - to either suppress viral replication, or prevent possible flares in disease activity. Such patients should be considered for liver transplantation and selection of the appropriate HBV therapy should be made in consultation with the local liver transplant program. Lamivudine and adefovir have been shown to improve hepatic function in such patients and may stave off the need for liver transplantation (147-149). However, the development of resistant mutants can be associated with flares of hepatitis and hepatic decompensation. Thus, it is preferable to use drugs (entecavir or tenofovir) with the lowest rates of resistance. Combination adefovir plus lamivudine is an option. Another alternative is the combination of tenofovir and emtricitabine, which is available as a single tablet for daily use. In a study of $112 \mathrm{HBV}$ patients with decompensated cirrhosis (126), a higher proportion of patients receiving tenofovir plus emtricitabine achieved HBV DNA $<400$ copies/mL and HBeAg seroconversion compared with those who received tenofovir or entecavir monotherapy. However, liver function improved in all patients (126). The renal function must be monitored carefully if tenofovir or adefovir are used in cirrhotic patients because these patients are prone to renal dysfunction.

\section{THE MANAGEMENT OF HEPATITIS B IN SPECIAL PATIENT POPULATIONS}

Since the last consensus update, additional data for patient groups with special needs became available. The consensus committee has updated the guidelines for the special patient population to assist clinicians and health care providers in providing health services and treatment to these groups of patients.

\section{Management of HBV and HIV coinfection}

Due to similar transmission routes, coinfection with HBV in patients with HIV is common. There are approximately 40 million HIV-infected people worldwide and it is estimated that approximately $10 \%$ (ie, approximately four million) of HIV-positive persons also have chronic hepatitis B $(150,151)$. Based on a 2008 modelling studies and literature review (152), the epidemiology of HBV and HIV coinfection in Canada is poorly defined. It is estimated that of $16,000 \mathrm{HIV}$-positive persons, approximately 6400 (9.8\%) are coinfected with HBV (152). HIV coinfection increases the risk of liver decompensation, cirrhosis and HCC. HBsAg and $\mathrm{HBeAg}$ seroconversion rates are reduced and HBV DNA levels are higher (153). French mortality studies describe an increasing proportion of liver-related deaths $(13.4 \%$ to $15.4 \%)$ in persons with HIV over a five-year interval (2000 to 2005), with a concomitant increase in deaths from HCC from $15 \%$ to $25 \%$ (154). The Multicenter AIDS Cohort study reported a 19-fold increase in liverrelated mortality in HBV/HIV coinfected patients compared with HIV monoinfected patients (155). A meta-analysis performed on data from 12,382 patients enrolled in 11 studies revealed a significant effect of HIV/HBV coinfection on mortality both before and after commencement of HAART (156).

Currently approved anti-HBV oral nucleos(t)ide analogues with anti-HIV activity include lamivudine, telbivudine, emtricitabine, tenofovir and entecavir (157-160). In HIV coinfected persons on long-term lamivudine (without a second anti-HBV drug), the rate of lamivudine-resistant HBV is approximately $90 \%$, potentially leading to severe hepatitis and fatalities $(161,162)$. Entecavir is active against HIV and when given as monotherapy can result in the HIV lamivudine resistance mutation (rtM184V), limiting HIV therapeutic options (158). Regardless, given its overall trivial activity against HIV, HIV providers would not choose entecavir because it would not improve the potency of an anti-HIV regimen. For HBV and HIV coinfection, tenofovir plus either lamivudine or emtricitabine is usually recommended in HAART. If tenofovir is contraindicated (such as due to chronic kidney disease), then entecavir should be added; however, due to cross-resistance, the durability of entecavir against HBV may be compromised by previous HBV treatment failure with regimens including emtricitabine or lamivudine (163). Several international expert guidelines including the United States Department of Health and Human Services, the International AIDS Society, the European AIDS Society and the British HIV Society state that antiretroviral treatment should be initiated, regardless of CD4 $\mathrm{T}$ cell count, in patients with HBV coinfection when treatment of $\mathrm{HBV}$ is indicated (164-166). If HAART with anti-HBV activity is stopped for any reason, an anti-HBV agent should be added to avoid HBV reactivation and hepatocellular disease flares (167-169). Immune reconstitution syndrome in advanced HIV disease may occur after initiating HAART, and could result in a flare of hepatitis due to increased immune-mediated hepatocellular injury $(170,171)$.

The treatment of the HBV and HIV coinfected individual is complex and, ideally, these patients should be managed with a multidisciplinary 
approach by specialists with an understanding of both infectious disease and liver disease. The baseline status of both HBV and HIV infection needs to be clearly defined, including routine laboratory tests for HIV (ie, CD4 T cell count, HIV RNA plasma viral load, etc). Other recommended tests include creatinine (estimated glomerular filtration rate), liver enzymes and liver function tests, and a CBC. The assessment of HBV status is as noted above and should include HBV DNA, HBeAg, anti-HBe, hepatic synthetic function, liver enzymes, abdominal ultrasound, and assessment of liver disease via noninvasive modalities (ie, transient elastography or FibroScan) or liver biopsy if transient elastography is not available. Baseline renal function including creatinine (estimated glomerular filtration rate) and urinalysis should be assessed given the possible association between tenofovir and chronic kidney disease and decreased bone mineral density in the HIV-positive population (172). Of note, patients with evidence of past infection to hepatitis B (anti-HBc- and anti-HBs- or anti-HBepositive) should be tested for $\mathrm{HBs} A g$ alone at yearly intervals to detect a possible reactivation. Patients with isolated anti-HBc should be vaccinated and vaccine nonresponders should be tested yearly for $\mathrm{HBs} \mathrm{Ag}$, anti-HBc and anti-HBs to identify new infections (173).

\section{Recommendations}

26. HAART should be initiated, regardless of CD4 count, in patients with HBV HIV coinfection when treatment of HBV is indicated (Class 2, Level B).

27. Whenever HAART is given, the goal is complete HIV and HBV virological suppression, to avoid the selection of drugresistant mutant virus (Class 1, Level B).

28. If a patient requires treatment for HIV alone or for both HIV and HBV, include tenofovir plus either emtricitabine or lamivudine with an appropriate third anti-HIV drug (Class 1, Level B).

29. The withdrawal of an HBV-active antiviral drug could result in worsening of the HBV infection; it should be avoided if possible, but if done, HBV DNA and ALT need to be carefully monitored (Class 1, Level B).

30. If tenofovir is stopped and an alternate anti-HBV agent is used, then an appropriate anti-HIV agent should be substituted (Class 1, Level B).

31. HBV and HIV coinfected individuals should also undergo surveillance for HCC (Class 1, Level B).

\section{Management of HBV and $\mathrm{HCV}$ coinfection}

Dual infection with HBV and HCV can also occur due to shared parenteral routes of transmission. HCV, like HBV, is a hepatotropic pathogen and available natural history studies suggest that HBV/HCV coinfection increases the risk of progressive liver disease including cirrhosis and HCC (174-183). Recent in vitro studies using novel cell-culture systems have shown that HBV and HCV can replicate within the same hepatocyte without direct viral interference $(184,185)$, suggesting that indirect mechanisms mediated by host immunity likely determine disease dominance and outcome. Currently, there are no standard of care recommendations for treatment of $\mathrm{HBV} / \mathrm{HCV}$ coinfection. The dynamic nature of both infections warrants ongoing monitoring $(186,187)$. All patients should have complete assessment of liver disease severity and HBV DNA and HCV RNA measurements. The dominant viral infection should be the focus of treatment. Subjects with high levels of HBV DNA but negative HCV RNA should be treated as any other HBVinfected patient. If the $\mathrm{HBV} / \mathrm{HCV}$ coinfected patient appears to have inactive chronic hepatitis $\mathrm{B}$, or occult hepatitis $\mathrm{B}$, and the HCV RNA is positive, these patients should be treated as for other patients with chronic HCV infection. In the largest clinical trial published to date on treatment of HBV and HCV confection (188), the rates of HCV sustained virological response to PEG IFN and ribavirin was similar between $\mathrm{HBV} / \mathrm{HCV}$ coinfected compared with $\mathrm{HCV}$ monoinfected patients. However, as have been reported in a number of published case series, the authors also observed a high percentage of HBV reactivation during treatment-induced suppression of HCV $(189,190)$. Therefore, if the patient has detectable HBV DNA, these patients should be considered for combination anti-HCV therapy with antiHBV nucleos(t)ide analogue therapy (ie, entecavir or tenofovir). If this is not possible, HBV DNA levels should be monitored every four weeks while on anti-HCV therapy and treatment instituted in patients with HBV flares. Finally, therapeutic trials evaluating combinations of $\mathrm{HCV}$ antivirals, especially with the newer protease or polymerase inhibiters along with anti-HBV nucleos $(\mathrm{t})$ ide analogues are necessary to establish the optimal regimen for treatment of HBV and HCV coinfection.

\section{Recommendations}

32. Patients dually infected with HBV and HCV should undergo an individualized approach to treatment including ongoing HBV DNA and HCV RNA testing by standardized sensitive PCR assays and assessment of baseline liver disease (Class 2, Level B).

33. If antiviral treatment is warranted the dominant virus should be the focus of therapy (Class 2, Level B).

34. Treatment-induced HCV suppression can lead to HBV-related disease flares warranting HBV DNA monitoring while receiving anti-HCV therapy. Patients should be considered for anti-HBV nucleos(t)ide analogue therapy if HBV DNA is detectable (Class 2, Level B).

\section{Management of HBV before pregnancy}

Decisions on antiviral therapy in women of childbearing age must take into account the woman's desire for a family. Due to its finite duration of treatment, PEG IFN may be an attractive option in these women, especially if they have other favourable characteristics and no contraindications for interferon therapy (ie, low viral load, high ALT, genotype $\mathrm{A}$ or $\mathrm{B}$ ), if the patient agrees to delay pregnancy until after completion of the 48-week treatment course. Women needing immediate HBV treatment and planning a family should be treated with drugs that are safe in pregnancy (see below).

\section{Management of HBV during pregnancy}

Continuation of anti-HBV therapy initiated before pregnancy: If a patient becomes pregnant while already on anti-HBV therapy and has not achieved the necessary virological or biochemical end points of treatment, then it is recommended that treatment be continued throughout pregnancy but with an antiviral agent that is considered safe to use during pregnancy (see below). Treatment should be continued until the same treatment goals are achieved as in nonpregnant women.

Initiation of anti-HBV therapy during pregnancy: Initiation of antiHBV therapy may be considered in pregnancy for two main reasons. First, a small proportion of HBV-infected women may have liver disease that merits treatment. Second, there is evidence that administration of anti-HBV therapy in late pregnancy to women with high concentrations of HBV DNA can reduce the risk of mother-to-infant transmission (ie, vertical transmission) greater than that provided by passive-active immunoprophylaxis with combined hepatitis B immune globulin (HBIG) and HBV vaccination. The most common route of HBV infection globally is vertical transmission, mainly during parturition. The majority of infants infected become chronic carriers and remain at subsequent risk for future liver disease. As shown in the 1980s, administering both HBIG and HBV vaccine to infants born to HBV-infected women is $>90 \%$ effective in preventing mother-toinfant transmission, justifying universal screening of pregnant women for HBsAg, and passive-active immunoprophylaxis of all infants at birth $(191,192)$. However, it is estimated that there is still an approximately $10 \%$ residual risk of HBV vertical transmission despite administration of both $\mathrm{HBIG}$ and $\mathrm{HBV}$ vaccine with $\mathrm{HBeAg}$ positivity and 
TABLE 10

\section{Summary of Nanjing single-centre experience of mother- to-infant transmission of hepatitis $B$ virus (HBV) versus HBV prophylaxis failure rate}

\begin{tabular}{lc}
\hline Maternal HBV DNA level at delivery* & Infection rate, $\mathbf{n} \mathbf{n}(\%)$ \\
\hline$<6 \log _{10}$ copies/mL & $0 / 0(0)$ \\
$6-6.99 \log _{10}$ copies/mL $\left(2 \times 5-6 \log _{10} \mathrm{IU} / \mathrm{mL}\right)$ & $9 / 298(3.2)$ \\
$7-7.99 \log _{10}$ copies $/ \mathrm{mL}\left(2 \times 6-7 \log _{10} \mathrm{IU} / \mathrm{mL}\right)$ & $29 / 531(5.46)$ \\
$>8 \log _{10}$ copies $/ \mathrm{mL}\left(2 \times 7-8 \log _{10} \mathrm{IU} / \mathrm{mL}\right)$ & $23 / 239(9.62)$ \\
\hline
\end{tabular}

*1 IU/mL = approximately five virus genome copies (or virus genome equivalents)/mL. Data from reference 198

high levels of plasma HBV DNA being the main virological predictors of prophylaxis failure (193). If maternal HBV DNA is $>10^{9}$ copies $/ \mathrm{mL}$, the risk may be as high as $32 \%$. In one study of Australian pregnant women with chronic hepatitis B (194), no transmissions were observed in 91 cases when maternal HBV DNA was $<10^{8}$ copies/mL (194). However, in other studies of $\mathrm{HBeAg}$-positive mothers, the residual risk of HBV mother-to-infant transmission despite HBIG and vaccination is estimated to be approximately $15 \%(191,193,195-197)$. Pan et al (198) presented data at the 2011 Annual American Association for the Study of Liver Disease (AASLD) meeting and reviewed the outcomes in $>1000 \mathrm{HBeAg}$-positive pregnant women. Vertical transmission was defined as infant $\mathrm{HBs} \mathrm{Ag}$ positivity at seven to 12 months of age. The maternal predelivery HBV DNA levels were stratified and correlated with the corresponding infected rates at birth. In 1068 consecutive infants born to $\mathrm{HBeAg}$-positive mothers receiving standard passive-active immunoprophylaxis, 61 of 1068 infants were $\mathrm{HBsAg}$ positive at seven to 12 months of age (approximately 5\% immunoprophylaxis failure rate). No cases of vertical transmission occurred when maternal HBV DNA was $<6 \log _{10}$ copies/mL (approximately $2 \times 5$ $\log _{10} \mathrm{IU} / \mathrm{mL}$ ) (Table 10). Other maternal risk factors include mothers with postpartum hemorrhage, meconium-stained amniotic fluid and oligohydramnios (198). Infant factors included HBV DNA venous blood, high HBsAg levels and absence of anti-HBs at birth (199).

There is convincing evidence that anti-HBV therapy reduces the risk of HBV mother-to-infant transmission. One randomized controlled trial (RCT) from China and a case-control study from the Netherlands demonstrated the efficacy of anti-HBV therapy in late pregnancy added to HBIG and HBV vaccine in the prevention of mother-to-infant transmission of HBV with lamivudine $(200,201)$. Similarly, a recent casecontrol study has demonstrated the efficacy of telbivudine (120) (Table 11). RCT and case-control data are not available with the two most potent HBV nucleoside inhibitors, entecavir and tenofovir.

The optimal gestational age to start anti-HBV therapy has not been established. The higher the HBV DNA, the longer it takes to suppress; however, full suppression is not likely necessary, given the efficacy of HBIG and vaccine at low levels of maternal viremia. The RCT of lamivudine started therapy at week 32 of gestation with a $2.63 \log _{10}$ decrease in HBV DNA at delivery (200). The case-control study of telbivudine started therapy between week 20 and 32 of gestation with a $5.72 \log _{10}$ decrease in HBV DNA at delivery (120). A recent abstract presented by Han et al at the 2011 AASLD meeting has shown that initiation in the third trimester was just as effective as in the second trimester (202). Thus, the consensus meeting agreed that in the majority of cases (ie, no signs of threatened preterm delivery and possible intrauterine transmission), initiation in the last trimester of pregnancy (after 28 weeks) is reasonable to lower maternal viremia before parturition.

When considering choice of antiviral therapy during pregnancy, the FDA has classified tenofovir, telbivudine and emtricitabine as pregnancy category B (no evidence of risk to humans according to adequate well-controlled studies), and lamivudine, entecavir and adefovir as category $\mathrm{C}$ drugs (risk cannot be ruled out) (203). Data from
TABLE 11

\section{Summary of two studies evaluating maternal antiviral therapy to prevent mother-to-infant transmission of hepatitis B virus (HBV)}

\begin{tabular}{|c|c|c|}
\hline Parameter & Xu et al, 2009 (200) & Han et al, 2011 (120) \\
\hline Intervention & $\begin{array}{l}\text { Lamivudine } 100 \text { mg once } \\
\text { daily versus placebo }\end{array}$ & $\begin{array}{l}\text { Telbivudine } 600 \text { mg once } \\
\text { daily versus untreated } \\
\text { controls }\end{array}$ \\
\hline Timing of treatment & $\begin{array}{c}\text { Week } 32 \text { gestation to } \\
\text { week } 4 \text { postpartum }\end{array}$ & $\begin{array}{l}\text { Week 20-32 gestation to } \\
\text { week } 4 \text { postpartum }\end{array}$ \\
\hline Design & RCT, double-blind & Nonrandomized, open-label \\
\hline $\begin{array}{l}\text { Maternal HBV } \\
\text { criteria }\end{array}$ & $\begin{array}{l}\text { HBV DNA }>10^{9} \text { virus } \\
\text { copies/mL (one subject } \\
\text { was } \mathrm{HBeAg}-\text { ) }\end{array}$ & $\begin{array}{l}\text { HBV DNA }>10^{7} \text { virus } \\
\text { copies } / \mathrm{mL} \text { and } \mathrm{HBeAg}+\end{array}$ \\
\hline$n$ & 56 lamivudine, 59 placebo & 135 telbivudine, 94 controls \\
\hline $\begin{array}{l}\text { Caesarean section } \\
\text { rate }\end{array}$ & $\begin{array}{l}\text { Approximately } 50 \% \text { in both } \\
\text { groups }\end{array}$ & $\begin{array}{l}56 \% \text { telbivudine, } \\
47 \% \text { placebo }\end{array}$ \\
\hline $\begin{array}{l}\text { HBV DNA, } \log _{10} \\
\text { copies } / m L\end{array}$ & $\begin{array}{l}\text { Lamivudine } 2.2 \times 10^{9} \\
\text { Placebo } 2.7 \times 10^{9}\end{array}$ & $\begin{array}{l}\text { Telbivudine } 8.10 \\
\text { control } 7.98\end{array}$ \\
\hline $\begin{array}{l}\text { HBV DNA at } \\
\text { delivery, } \log _{10} \\
\text { copies/mL }\end{array}$ & $\begin{array}{l}\text { Lamivudine } 5.1 \times 10^{7} \\
\text { Placebo } 2.2 \times 10^{9}\end{array}$ & $\begin{array}{l}\text { Telbivudine } 2.4 \\
\text { control } 7.82\end{array}$ \\
\hline HBsAg+ infants & $\begin{array}{l}\text { 18\% lamivudine, } 39 \% \\
\text { placebo }(P=0.014)\end{array}$ & $\begin{array}{l}0 \% \text { telbivudine, } 8 \% \text { control } \\
(P=0.002)\end{array}$ \\
\hline Antiviral resistance & Not tested & Not reported \\
\hline
\end{tabular}

- Negative; + Positive; RCT Randomized controlled trial

the June 2011 antiretroviral pregnancy registry for nucleoside analogue exposure in the first trimester indicate that there is overall minimal teratogenic risk (204). According to prescribing information, it has not been recommended that mothers breastfeed their infants while taking oral nucleos $(\mathrm{t})$ ide analogues $(205,206)$. Although some studies show that nucleoside analogues are secreted at minimal or extremely low levels in breastmilk (ie, $0.03 \%$ of the recommended infant dose of tenofovir) and can be safely used $(207,208)$, the consensus position is that breastfeeding is not recommended if receiving antiHBV nucleos(t)ide analogue therapy. Thus, if treatment is only indicated to prevent vertical transmission, and if the mother wishes to breastfeed, antiviral treatment should be stopped after delivery due to unknown potential risk. However, mothers should be followed for possible virological and biochemical flares after stopping the nucleos $(\mathrm{t})$ ide analogue. Breastfeeding is not contraindicated for infants born to $\mathrm{HBs} \mathrm{Ag}$-positive mothers and is encouraged by the Canadian Paediatric Society and the American Academy of Pediatrics $(209,210)$. The risk of HBV transmission is low and comparable for breastfed and formulafed infants after administration of HBIG at birth followed by HBV vaccination (211-213).

Finally, a number of practical issues should be considered in using oral anti-HBV therapy in highly viremic pregnant women. Such use may still be considered 'off-label' and the development of antiviral resistance has not been studied in this setting. Although lamivudine is recommended by other expert guidelines, vertical transmission has been reported despite maternal therapy (214). There is extensive experience with both tenofovir and lamivudine use in HIV-positive pregnant women and in breastfeeding. It seems logical to choose tenofovir as primary treatment given its better resistance profile, and because the indication is to reduce high maternal viral load. Thus, the consensus recommended tenofovir as first-line treatment during pregnancy, telbivudine or lamivudine is an alternative if tenofovir is contraindicated. In all cases, an informed discussion with such patients is warranted, including presenting the pros and cons of antiviral therapy. If treatment is not initiated during pregnancy or if treatment is stopped after delivery, the mother should be closely monitored for hepatocellular disease flares. 


\section{Recommendations}

35. All pregnant women should be screened with HBsAg and if positive tested for HBV DNA, HBeAg and ALT (Class 1, Level A).

36. All infants born to HBsAg-positive women should receive both $\mathrm{HBIG}$ and $\mathrm{HBV}$ vaccine within $12 \mathrm{~h}$ of birth (Class 1, Level A).

37. HBV treatment should be considered in high-risk mothers to reduce the risk of mother-to-infant transmission if high viral loads $\left(>2 \times 10^{6} \mathrm{IU} / \mathrm{mL}\right.$ or $>7 \log _{10}$ copies $\left./ \mathrm{mL}\right)$, and especially if they also have complications during pregnancy (threatened miscarriage, preterm delivery), or birth of an infant with previous prophylaxis failure (Class 2, Level B).

38. Because treatment goals are to lower maternal viremia before parturition, then initiation in the third trimester (ie, after 28 weeks' gestation) is considered acceptable (Class 2, Level B).

39. If treatment is not initiated, patients should be monitored during pregnancy and postpartum for flares and for withdrawal flares after nucleos(t)ide analogue treatment if stopped (Class 1, Level A).

40. The recommended first-line treatment during pregnancy is tenofovir (FDA category B), telbivudine should be used if contraindications to tenofovir therapy to lower viral loads and if treatment is not expected to be prolonged postpartum (Class 2, Level B).

\section{Management of hepatitis B-related renal disease}

Renal involvement is one of the most common extrahepatic manifestations of HBV infection, and usually manifests as immune complexassociated glomerulopathy, such as membranous glomerulonephritis, membranoproliferative glomerulonephritis, mesangioproliferative glomerulonephritis and immunoglobulin A nephropathy, as well as other extrahepatic diseases such as vasculitis and polyarteritis nodosa $(215,216)$. Suppression of HBV DNA can result in improved renal function in these patients. There is evidence that patients with HBVinduced immune-complex mediated disease may have increased rates of responsiveness to interferon therapy or nucleos(t)ide analogues (217-225). Most cases reports are with lamivudine but withdrawal of antiviral therapy can lead to relapse of nephrotic syndrome and, as noted, long-term lamivudine treatment is limited by the potential emergence of drug-resistant mutations and hepatic flares $(221,226)$. There is one case reported on entecavir therapy for hepatitis B-related membranous nephropathy, which may be an option especially if prolonged treatment courses are required (227). Tenofovir (and adefovir) should be used with caution in this population, because these drug classes may be associated with renal dysfunction. Because all antiviral agents are excreted by the kidney, dose adjustments are required in renal failure.

\section{Management of HBV during immunosuppression}

Reactivation of HBV is defined as an increase in hepatitis B viral replication in patients with serum HBsAg-positive chronic hepatitis B or in patients with resolved (past) HBV infection $(228,229)$. The latter scenario may be due to occult hepatitis B infection, which is characterized by the presence of low-level HBV DNA in serum, liver and peripheral blood mononuclear cells detected by highly sensitive kinetic PCR assays, despite serum HBsAg negativity. Often, anti-HBc is the sole serological marker of occult hepatitis B infection $(230,231)$. $\mathrm{HBV}$ reactivation can occur spontaneously, especially in $\mathrm{HBeAg}$ negative chronic hepatitis $\mathrm{B}$, or be a result of immunomodulatory therapy. Examples of the latter scenario include cancer chemotherapy, treatment with rituximab (due to its effect on humoral immunity), HIV-related immunosuppression of cellular immunity, corticosteroid therapy (especially because the HBV enhancer has glucocorticoiddependent activity), immune modulation for autoimmune conditions, solid organ transplantation (heart, lung, kidney) and bone marrow transplant recipients (232-237). The reactivation of HBV replication in occult hepatitis B can lead to so-called reverse seroconversion, development of serum HBsAg positivity and active hepatitis B infection. It should be noted that even the presence of anti-HBs is not protective, although the risk of reactivation is significantly lower in occult hepatitis B infection compared with chronic hepatitis B (238). Occult hepatitis B reactivation has been described in HIV-related immunosuppression and in solid organ transplantation, but most of the data are from case reports within the oncology literature due to intense immunosuppression such as regimens involving rituximab-steroid combination with an overall estimated risk of 3\% (239-243). Recent multisite American data presented at the AASLD 2011 meeting of $>10,000$ cancer patients receiving chemotherapy reported that nearly one-quarter of cancer patients that were either $\mathrm{HBsAg}$ - and/or antiHBc-positive had reactivation of HBV. Only a small percentage underwent HBV screening before reactivation and/or received HBV prophylaxis. Furthermore, patients who received prophylaxis had a dramatically lower all-cause mortality (22\%) compared with those treated after reactivation (72\%) (244). Thus, persons at risk for HBV are not being adequately screened before chemotherapy, resulting in preventable reactivation.

Typically, HBV reactivation begins with a sudden increase in viral replication during immune suppression (229). Diagnostic markers of this phase are an increase in serum HBV DNA more than one log above baseline, anti-HBc immunoglobulin $\mathrm{M}$ and $\mathrm{HBeAg}$. The second phase develops when immunosuppression is withdrawn. Immune restoration is followed by a rapid immune-mediated destruction of HBVinfected hepatocytes leading to acute liver failure, chronic hepatitis or cirrhosis. Diagnostic markers of this phase are aminotransferase levels three times above the upper limit of normal, and even jaundice.

The consequences of HBV reactivation in HBsAg-positive chronic carriers include subtle changes in transaminases to fulminant hepatic failure and even death without liver transplantation (229). The mortality from HBV reactivation ranges from $4 \%$ to $60 \%$, with the greatest risk related to hematological malignancies. Therefore, all $\mathrm{HBsAg}$-positive patients should receive anti-HBV prophylaxis with a nucleos(t)ide analogue before chemotherapy (245). To date, most studies have used lamivudine $(245,246)$, and a meta-analysis of 21 studies showed a mortality benefit (247). There are data from three RCTs of lamivudine prophylaxis in patients undergoing chemotherapy, involving transarterial chemoembolization for HCC (248) or lymphoma treatment $(249,250)$. However, most HBV treatment provider experts prefer the use of anti-HBV agents with higher antiviral potency and lower risk of resistance (ie, tenofovir or entecavir) with entecavir being preferred in cases with renal disease (251-254). HBV DNA should be monitored while on treatment to exclude noncompliance and virological breakthrough. Pre-emptive therapy is more effective then after reactivation; thus, ideally, treatment is started one month before immmunosuppression onset (250). Therapy should be continued until 12 months after the last dose of the immunomodulatory drug.

In HBsAg-negative patients (ie, occult HBV infection), prophylactic antiviral therapy is not routinely recommended, because the risk of reactivation is considered to be low overall, but all patients should have periodic monitoring of HBV serology. In cases with significant immunosuppression and if HBV DNA levels are unable to be monitored regularly, the safest strategy may be emperical prophylaxis and treat as for a HBsAg-positive patient. If HBV DNA is detectable before treatment, antiviral prophylaxis is recommended. However, if HBV DNA is undetectable, HBV DNA levels should be checked every one to three months, and with any increasing viremia start antiviral prophylaxis.

\section{Recommendations}

41. All patients undergoing chemotherapy or treatment with other immunosuppressive therapies should be screened for $\mathrm{HBsAg}$ (Class 1, Level A). 
42. Ideally, all patients should also be checked for protective hepatitis B surface antibodies (anti-HBs) and, if negative, receive the $\mathrm{HBV}$ vaccine. However, $\mathrm{HBV}$ testing and vaccination should not delay the initiation of chemotherapy in oncology patients (Class 2, Level A).

43. Those testing positive for $\mathrm{HBs} \mathrm{Ag}$ should receive antiviral prophylaxis ideally starting one month before treatment and continued for at least 12 months after last dose of immunosuppressive drug, and should be monitored during and after therapy (Class 2, Level B).

44. In certain special circumstances, ie, if patients test positive for anti-HBc and are undergoing intense immunosuppression (ie, rituximab-steroid-containing regimens, treatment for lymphoma or hematological malignancies), they should be referred to a specialist for HBV DNA testing and monitoring. If the HBV DNA is positive, these patients may also be considered for antiviral therapy (Class 2, Level C).

\section{HBV-infected health care providers}

Many jurisdictions have developed guidelines that restrict the practice of health care providers who perform exposure prone procedures (EPP). According to the Society for Healthcare Epidemiology of America, an EPP is one that involves one or more of the following: digital palpation of a needle tip in a body cavity or the simultaneous presence of a sharp instrument and a health care worker's finger in a blind or highly confined anatomical site; repair of major traumatic injuries; and manipulation or removal of oral or perioral tissue including tooth structures $(255,256)$. Overall, the risk of HBV transmission from health care provider to patient is low, and most cases reported in the scientific literature occurred before the adoption of or due to lapses in universal precautions (routine practices). Moreover, given universal childhood vaccination for $\mathrm{HBV}$ in Canada, fewer patients and health care professionals are at risk of acquiring acute hepatitis B. However, hepatitis B-infected health professionals may choose to take treatment to reduce viral load and thereby preserve their careers. There is no definitive level of HBV DNA below which infection cannot occur, although the lowest viral concentration associated with documented transmission was 4000 copies/mL (approximately $800 \mathrm{IU} / \mathrm{mL}$ ) (257).

A HBV DNA level of $<2000 \mathrm{IU} / \mathrm{mL}(10,000$ copies/mL) was chosen by the European Consensus Group in 2003 (257) and the Society for Healthcare Epidemiology of America in 2010 (256) for the performance of EPPs. In the United Kingdom, if HBV DNA is $<200 \mathrm{IU} / \mathrm{mL}$, surgeons can continue to operate. In general, we agree with these recommendations but an undetectable HBV DNA by sensitive kinetic PCR should be the goal. Therefore, any HBV-positive health care provider with high viral load should refrain from performing EPPs, except on patients who are either HBV-infected (HBsAg positive) or HBV immune (anti-HBs positive) unless their infectivity status changes - whether by natural immunity or from antiviral therapy. An HBV-infected physician with HBV DNA < $2000 \mathrm{IU} / \mathrm{mL}$ $(10,000$ copies $/ \mathrm{mL})$ should be permitted to perform EPP using double gloves and universal precautions with the proviso that their personal physician provides regular (every three months) confirmation that his or her HBV DNA level is below this level.

\section{Management of HBV and HDV coinfection}

$\mathrm{HDV}$ is a small defective RNA virus that requires $\mathrm{HBs} \mathrm{Ag}$ to complete its lifecycle and propagate infection (258). HDV may be acquired as a coinfection simultaneously with hepatitis $\mathrm{B}$ or as a superinfection in a patient who already is a hepatitis B carrier. It is a difficult-to-treat infection that usually causes an aggressive hepatitis and is associated with a higher risk of cirrhosis and HCC than HBV monoinfection. HDV infection is uncommon in North American. Those at highest risk for HDV infection are HBsAg carriers who acquired their infection through injection drug use and immigrants from endemic regions (ie, Mediterranean countries, Eastern Europe and Latin America [5\% to $8 \%$ of HBsAg-positive carriers]) $(259,260)$. Patients with these risk factors, particularly in the setting of a high ALT with undetectable HBV DNA, should be tested for HDV antibody. If the HDV antibody is positive, active infection should ideally be confirmed with an HDV RNA; treatment considered in those with active infection. The HDV RNA assay is not commercially available, and home-grown assays are not standardized. Patients with active hepatitis D should be treated in expert centres. Unfortunately, the infection is difficult to treat. Lamivudine appears to have no role in the management of HDV and clinical data using the more potent oral anti-HBV agents entecavir and tenofovir are lacking. A recent Cochrane review of six randomized trials using interferon treatment showed that while interferon alpha is effective for suppressing viral replication, it does not eradicate infection (261). In a recent international study conducted in chronic hepatitis D patients from Germany, Turkey and Greece, treatment with PEG IFN alpha-2a for 48 weeks, with or without adefovir, resulted in sustained HDV RNA clearance in approximately onequarter of patients with HDV infection (262). Although there was no difference in the biochemical and virological response (both HBV DNA and HDV RNA), the combination therapy group demonstrated a marked reduction in serum HBsAg levels, which correlated positively with HDV RNA reduction. Therefore, new studies using combination interferon and newer nucleoside analogues such as tenofovir may lead to better results in these patients. Treatment response should be monitored with HDV RNA testing at month 6 and in those who fail to achieve at least a 3-log drop, therapy should be discontinued. Alternatively, in the absence of HDV RNA monitoring, normalization of the ALT would suggest suppression of virus.

\section{Recommendations \\ 45. Hepatitis D should be treated with PEG IFN monotherapy at standard doses for a minimum of 12 months (Class 2, Level B). \\ 46. HDV RNA testing should be available (Class 1, Level A)}

FUNDING: Funding for this meeting was provided through an unrestricted grant from the Canadian Liver Foundation. The Canadian Liver Foundation has received donations from pharmaceutical companies that have products that were discussed at the meeting.

DISCLOSURES: This will serve as a general disclosure for all speakers and the members of the Writing Committee. Many, but not all of the speakers and writers have or have had relationships with the pharmaceutical companies. These relationships include having received research grants, honoraria for speaking engagements or for work on advisory boards related to all of the products discussed in this document.

Dr Coffin has received research support and/or speaker and consultant fees from Gilead, Roche, Bristol Myers Squibb and Merck pharmaceuticals.

Dr. Ma has received research support and consultant fees from Gilead, Merck, Roche and Vertex pharmaceuticals. 


\section{REFERENCES}

1. Sherman M, Shafran S, Burak K, et al. Management of chronic hepatitis B: Consensus guidelines. Can J Gastroenterol 2007;21(Suppl C):5C-24C.

2. Shiffman RN, Shekelle P, Overhage JM, Slutsky J, Grimshaw J, Deshpande AM. Standardized reporting of clinical practice guidelines: a proposal from the Conference on Guideline Standardization. Ann Intern Med 2003;139:493-8.

3. Guyatt GH, Oxman AD, Kunz R, et al. Going from evidence to recommendations. BMJ 2008;336:1049-51.

4. Guyatt GH, Oxman AD, Kunz R, et al. Incorporating considerations of resources use into grading recommendations. BMJ 2008;336:1170-3.

5. Guyatt GH, Oxman AD, Kunz R, Vist GE, Falck-Ytter Y, Schunemann HJ. What is "quality of evidence" and why is it important to clinicians? BMJ 2008;336:995-8.

6. Guyatt GH, Oxman AD, Vist GE, et al. GRADE: An emerging consensus on rating quality of evidence and strength of recommendations. BMJ 2008;336:924-6.

7. Jaeschke R, Guyatt GH, Dellinger P, et al. Use of GRADE grid to reach decisions on clinical practice guidelines when consensus is elusive. BMJ 2008;337:a744.

8. Schunemann HJ, Oxman AD, Brozek J, et al. Grading quality of evidence and strength of recommendations for diagnostic tests and strategies. BMJ 2008;336:1106-10.

9. Organization WH. Hepatitis B (Fact sheet no. 204). Geneva, Switzerland: World Health Organization, 2008.

10. Wu HX, Andonov A, Giulivi A, et al. Enhanced surveillance for childhood hepatitis B virus infection in Canada, 1999-2003. Int J Med Sci. 2005;2:143-6.

11. Decision Analysis on Screening for HBV in Immigrants. Statistics and Risk Assessment Section of the Blood Safety Surveillance and Health CareAcquired Infection Division, Population and Public Health Branch Health Canada, 2000.

12. Minuk GY, Uhanova J. Chronic hepatitis B infection in Canada. Can J Infect Dis 2011;12:351-6.

13. Lai CL, Ratziu V, Yuen MF, Poynard T. Viral hepatitis B. Lancet 2003;362:2089-94.

14. McMahon BJ. Natural history of chronic hepatitis B. Clin Liver Dis 2010;14:381-96.

15. Kwong JC, Crowcroft NS, Campitelli MA, Ratnasingham S, Daneman N, Deeks SL, Manuel DG. Ontario Burden of Infectious Disease Study Advisory Group; Ontario Burden of Infectious Disease Study (ONBOIDS): An OAHPP/ICES Report. Toronto: Ontario Agency for Health Protection and Promotion, Institute for Clinical Evaluative Sciences; 2010.

16. Shepard CW, Finelli L, Fiore AE, Bell BP. Epidemiology of hepatitis B and hepatitis B virus infection in United States children. Pediatr Infect Dis J 2005;24:755-60.

17. McMahon BJ, Schoenberg S, Bulkow L, et al. Seroprevalence of hepatitis B viral markers in 52,000 Alaska Natives. Am J Epidemiol 1993; 138:544-9.

18. 2007 British Columbia Annual Summary of Reportable Diseases. BC Centre for Disease Control, Monika Naus ed. Vancouver; 2008.

19. Expanded Programme on Immunization of the Department of Immunizations, Vaccines and Biologicals. WHO vaccinepreventable diseases monitoring system, 2007 global summary. Geneva (Switzerland), 2007.

20. Whittle H, Jaffar S, Wansbrough M, et al. Observational study of vaccine efficacy 14 years after trial of hepatitis $B$ vaccination in Gambian children. BMJ 2002;325:569.

21. Dentinger CM, McMahon BJ, Butler JC, et al. Persistence of antibody to hepatitis $\mathrm{B}$ and protection from disease among Alaska natives immunized at birth. Pediatr Infect Dis J 2005;24:786-92.

22. Liao SS, Li RC, Li H, et al. Long-term efficacy of plasma-derived hepatitis B vaccine: A 15-year follow-up study among Chinese children. Vaccine 1999;17:2661-6.

23. Yuen MF, Lim WL, Chan AO, Wong DK, Sum SS, Lai CL. 18-year follow-up study of a prospective randomized trial of hepatitis B vaccinations without booster doses in children. Clin Gastroenterol Hepatol 2004;2:941-5.

24. Banatvala J, Van Damme P, Oehen S. Lifelong protection against hepatitis B: The role of vaccine immunogenicity in immune memory. Vaccine. 2000;19:877-85.

25. Active Immunizing Agents Hepatitis B vaccine, Canadian Immunization guide Seventh Edition - 2006. David Butler-Jones, ed. Ottawa: Public Health Agency of Canada.
26. Mast EE, Weinbaum CM, Fiore AE, et al. A comprehensive immunization strategy to eliminate transmission of hepatitis B virus infection in the United States: Recommendations of the Advisory Committee on Immunization Practices (ACIP) Part II: immunization of adults. MMWR Recomm Rep 2006;55(RR-16):1-33; quiz CE1-4.

27. Villeneuve E, Vincelette J, Villeneuve JP. Ineffectiveness of hepatitis $B$ vaccination in cirrhotic patients waiting for liver transplantation. Can J Gastroenterol 2000;14(Suppl B):59B-62B.

28. Use of hepatitis $B$ vaccination for adults with diabetes mellitus: Recommendations of the Advisory Committee on Immunization Practices (ACIP). Morb Mortal Wkly Rep 2011;60:1709-11.

29. Lok AS, Lai CL, Wu PC. Prevalence of isolated antibody to hepatitis B core antigen in an area endemic for hepatitis B virus infection: Implications in hepatitis B vaccination programs. Hepatology 1988;8:766-70.

30. Al-Mekhaizeem KA, Miriello M, Sherker AH. The frequency and significance of isolated hepatitis B core antibody and the suggested management of patients. CMAJ 2001;165:1063-4.

31. Lee WM. Hepatitis B virus infection. N Engl J Med 1997;337:1733-45.

32. Liaw YF, Chu CM, Huang MJ, Sheen IS, Yang CY, Lin DY. Determinants for hepatitis B e antigen clearance in chronic type B hepatitis. Liver 1984;4:301-6.

33. Lok AS, Lai CL, Wu PC, Leung EK, Lam TS. Spontaneous hepatitis $\mathrm{B}$ e antigen to antibody seroconversion and reversion in Chinese patients with chronic hepatitis B virus infection. Gastroenterology. 1987;92:1839-43.

34. Liaw YF, Sheen IS, Chen TJ, Chu CM, Pao CC. Incidence, determinants and significance of delayed clearance of serum HBsAg in chronic hepatitis B virus infection: A prospective study. Hepatology 1991;13:627-31.

35. Yu MW, Hsu FC, Sheen IS, et al. Prospective study of hepatocellular carcinoma and liver cirrhosis in asymptomatic chronic hepatitis B virus carriers. Am J Epidemiol 1997;145:1039-47.

36. Liaw YF. Hepatitis B virus replication and liver disease progression: The impact of antiviral therapy. Antivir Ther 2006;11:669-79.

37. Fattovich G, Rugge M, Brollo L, et al. Clinical, virologic and histologic outcome following seroconversion from $\mathrm{HBeAg}$ to antiHBe in chronic hepatitis type B. Hepatology 1986;6:167-72.

38. Lin X, Robinson NJ, Thursz M, et al. Chronic hepatitis B virus infection in the Asia-Pacific region and Africa: Review of disease progression. J Gastroenterol Hepatol 2005;20:833-43.

39. Yim HJ, Lok AS. Natural history of chronic hepatitis B virus infection: What we knew in 1981 and what we know in 2005. Hepatology 2006;43(2 Suppl 1):S173-81.

40. Chen G, Lin W, Shen F, Iloeje UH, London WT, Evans AA. Past $\mathrm{HBV}$ viral load as predictor of mortality and morbidity from HCC and chronic liver disease in a prospective study. Am J Gastroenterol 2006;101:1797-803.

41. Iloeje UH, Yang HI, Su J, Jen CL, You SL, Chen CJ. Predicting cirrhosis risk based on the level of circulating hepatitis B viral load. Gastroenterology 2006;130:678-86.

42. Chen CJ, Yang HI, Su J, et al. Risk of hepatocellular carcinoma across a biological gradient of serum hepatitis B virus DNA level. JAMA 2006;295:65-73.

43. Yu MW, Yeh SH, Chen PJ, et al. Hepatitis B virus genotype and DNA level and hepatocellular carcinoma: A prospective study in men. J Natl Cancer Inst 2005;97:265-72.

44. Saldanha J, Gerlich W, Lelie N, Dawson P, Heermann K, Heath A. An international collaborative study to establish a World Health Organization international standard for hepatitis B virus DNA nucleic acid amplification techniques. Vox Sang 2001;80:63-71.

45. Del Poggio P, Colombo S. Is transient elastography a useful tool for screening liver disease? World J Gastroenterol 2009;15:1409-14.

46. Zhu X, Wang LC, Chen EQ, et al. Prospective evaluation of FibroScan for the diagnosis of hepatic fibrosis compared with liver biopsy/AST platelet ratio index and FIB-4 in patients with chronic HBV infection. Dig Dis Sci 2011;56:2742-9.

47. Coco B, Oliveri F, Maina AM, et al. Transient elastography: A new surrogate marker of liver fibrosis influenced by major changes of transaminases. J Viral Hepat 2007;14:360-9.

48. Arena U, Vizzutti F, Corti G, et al. Acute viral hepatitis increases liver stiffness values measured by transient elastography. Hepatology 2008;47:380-4. 
49. Chan HL, Wong GL, Choi PC, et al. Alanine aminotransferasebased algorithms of liver stiffness measurement by transient elastography (Fibroscan) for liver fibrosis in chronic hepatitis B. J Viral Hepat 2009;16:36-44

50. Eisenberg E, Konopniki M, Veitsman E, Kramskay R, Gaitini D, Baruch Y. Prevalence and characteristics of pain induced by percutaneous liver biopsy. Anesth Analg 2003;96:1392-6.

51. Piccinino F, Sagnelli E, Pasquale G, Giusti G. Complications following percutaneous liver biopsy. A multicentre retrospective study on 68,276 biopsies. J Hepatol 1986;2:165-73.

52. Huang JF, Hsieh MY, Dai CY, et al. The incidence and risks of liver biopsy in non-cirrhotic patients: An evaluation of 3806 biopsies. Gut 2007;56:736-7.

53. Colloredo G, Guido M, Sonzogni A, Leandro G. Impact of liver biopsy size on histological evaluation of chronic viral hepatitis: The smaller the sample, the milder the disease. J Hepatol 2003;39:239-44.

54. Crawford AR, Lin XZ, Crawford JM. The normal adult human liver biopsy: A quantitative reference standard. Hepatology 1998;28:323-31.

55. Jaroszewicz J, Calle Serrano B, Wursthorn K, et al. Hepatitis B surface antigen (HBsAg) levels in the natural history of hepatitis $B$ virus (HBV)-infection: A European perspective. J Hepatol 2010;52:514-22.

56. Sonneveld MJ, Rijckborst V, Boucher CA, et al. A comparison of two assays for quantification of Hepatitis B surface antigen in patients with chronic hepatitis B. J Clin Virol 2011;51:175-8.

57. Wursthorn K, Jaroszewicz J, Zacher BJ, et al. Correlation between the Elecsys HBsAg II assay and the Architect assay for the quantification of hepatitis B surface antigen $(\mathrm{HBsAg})$ in the serum. J Clin Virol 2011;50:292-6.

58. Chan HL, Wong VW, Wong GL, Tse CH, Chan HY, Sung JJ. A longitudinal study on the natural history of serum hepatitis B surface antigen changes in chronic hepatitis B. Hepatology 2010;52:1232-41

59. Brunetto MR, Oliveri F, Colombatto P, et al. Hepatitis B surface antigen serum levels help to distinguish active from inactive hepatitis B virus genotype D carriers. Gastroenterology 2010;139:483-90.

60. Chan HL, Wong GL, Tse CH, Chan HY, Wong VW. Viral determinants of hepatitis $B$ surface antigen seroclearance in hepatitis B e antigen-negative chronic hepatitis B patients. J Infect Dis 2011;204:408-14.

61. Brunetto MR, Moriconi F, Bonino F, et al. Hepatitis B virus surface antigen levels: A guide to sustained response to peginterferon alfa-2a in $\mathrm{HBeAg}$-negative chronic hepatitis B. Hepatology 2009:49:1141-50.

62. Moucari R, Mackiewicz V, Lada O, et al. Early serum HBsAg drop: A strong predictor of sustained virological response to pegylated interferon alfa-2a in $\mathrm{HBeAg}$-negative patients. Hepatology 2009;49:1151-7.

63. Norder H, Courouce AM, Coursaget P, et al. Genetic diversity of hepatitis B virus strains derived worldwide: Genotypes, subgenotypes, and HBsAg subtypes. Intervirology 2004;47:289-309.

64. Miyakawa Y, Mizokami M. Classifying hepatitis B virus genotypes. Intervirology 2003;46:329-38.

65. Palumbo E. Hepatitis B genotypes and response to antiviral therapy: A review. Am J Ther 2007;14:306-9.

66. Liu CJ, Kao JH, Chen DS. Therapeutic implications of hepatitis B virus genotypes. Liver Int 2005;25:1097-107.

67. Buster EH, Hansen BE, Lau GK, et al. Factors that predict response of patients with hepatitis $\mathrm{B}$ e antigen-positive chronic hepatitis $\mathrm{B}$ to peginterferon-alfa. Gastroenterology 2009;137:2002-9.

68. Janssen HL, van Zonneveld M, Senturk H, et al. Pegylated interferon alfa-2b alone or in combination with lamivudine for $\mathrm{HBeAg}$-positive chronic hepatitis B: A randomised trial. Lancet 2005;365:123-9.

69. Bruix J, Sherman M. Management of hepatocellular carcinoma: An update. Hepatology 2011;53:1020-2.

70. Bruix J, Sherman M. Management of hepatocellular carcinoma. Hepatology 2005;42:1208-36.

71. Yuen MF, Yuan HJ, Wong DK, et al. Prognostic determinants for chronic hepatitis B in Asians: Therapeutic implications. Gut 2005;54:1610-4.
72. Lok AS, Lai CL. A longitudinal follow-up of asymptomatic hepatitis B surface antigen-positive Chinese children. Hepatology $1988 ; 8: 1130-3$.

73. Chang MH, Hsu HY, Hsu HC, Ni YH, Chen JS, Chen DS. The significance of spontaneous hepatitis $\mathrm{B}$ e antigen seroconversion in childhood: With special emphasis on the clearance of hepatitis B e antigen before 3 years of age. Hepatology 1995;22:1387-92.

74. Yuen M-F, Yuan H-J, Wong DK-H. Prognostic determinants for chronic hepatitis B in Asians: Therapeutic implications. Gut 2005;54:1610-4

75. Prati D, Taioli E, Zanella A, et al. Updated definitions of healthy ranges for serum alanine aminotransferase levels. Ann Intern Med 2002;137:1-10.

76. Fung SK, Lok AS. Hepatitis B virus genotypes: Do they play a role in the outcome of HBV infection? Hepatology 2004;40:790-2.

77. Chan HL, Hui AY, Wong ML, et al. Genotype C hepatitis B virus infection is associated with an increased risk of hepatocellular carcinoma. Gut 2004;53:1494-8.

78. Chu CJ, Hussain M, Lok AS. Hepatitis B virus genotype B is associated with earlier $\mathrm{HBeAg}$ seroconversion compared with hepatitis B virus genotype C. Gastroenterology 2002;122:1756-62.

79. Sanchez-Tapias JM, Costa J, Mas A, Bruguera M, Rodes J. Influence of hepatitis $B$ virus genotype on the long-term outcome of chronic hepatitis B in western patients. Gastroenterology 2002;123:1848-56.

80. Brook MG, McDonald JA, Karayiannis P, et al. Randomised controlled trial of interferon alfa 2A (rbe) (Roferon-A) for the treatment of chronic hepatitis $\mathrm{B}$ virus (HBV) infection: Factors that influence response. Gut 1989;30:1116-22.

81. Brunetto MR, Oliveri F, Colombatto P, Coco B, Ciccorossi P, Bonino F. Treatment of $\mathrm{HBeAg}$-negative chronic hepatitis B with interferon or pegylated interferon. J Hepatol. 2003;39(Suppl 1):S164-7.

82. Craxi A, Di Bona D, Camma C. Interferon-alpha for HBeAgpositive chronic hepatitis B. J Hepatol 2003;39(Suppl 1):S99-105.

83. Perrillo RP, Schiff ER, Davis GL, et al. A randomized, controlled trial of interferon alfa- $2 \mathrm{~b}$ alone and after prednisone withdrawal for the treatment of chronic hepatitis B. The Hepatitis Interventional Therapy Group. N Engl J Med 1990;323:295-301.

84. Wong DK, Cheung AM, O'Rourke K, Naylor CD, Detsky AS, Heathcote J. Effect of alpha-interferon treatment in patients with hepatitis B e antigen-positive chronic hepatitis B. A meta-analysis. Ann Intern Med 1993;119:312-23.

85. van Zonneveld M, Flink HJ, Verhey E, et al. The safety of pegylated interferon alpha-2b in the treatment of chronic hepatitis B: Predictive factors for dose reduction and treatment discontinuation. Aliment Pharmacol Ther 2005;21:1163-71.

86. Lau GK, Piratvisuth T, Luo KX, et al. Peginterferon alfa-2a, lamivudine, and the combination for $\mathrm{HBe} \mathrm{Ag}$-positive chronic hepatitis B. N Engl J Med 2005;352:2682-95.

87. Niederau C, Heintges T, Lange $S$, et al. Long-term follow-up of $\mathrm{HBeAg}$-positive patients treated with interferon alfa for chronic hepatitis B. N Engl J Med 1996;334:1422-7.

88. Lau DT, Everhart J, Kleiner DE, et al. Long-term follow-up of patients with chronic hepatitis B treated with interferon alfa. Gastroenterology 1997;113:1660-7.

89. Lin SM, Sheen IS, Chien RN, Chu CM, Liaw YF. Long-term beneficial effect of interferon therapy in patients with chronic hepatitis B virus infection. Hepatology 1999;29:971-5.

90. Lok AS, Chung HT, Liu VW, Ma OC. Long-term follow-up of chronic hepatitis B patients treated with interferon alfa. Gastroenterology 1993;105:1833-8.

91. Korenman J, Baker B, Waggoner J, Everhart JE, Di Bisceglie AM, Hoofnagle JH. Long-term remission of chronic hepatitis B after alpha-interferon therapy. Ann Intern Med 1991;114:629-34.

92. Krogsgaard K. The long-term effect of treatment with interferonalpha 2a in chronic hepatitis B. The Long-Term Follow-up Investigator Group. The European Study Group on Viral Hepatitis (EUROHEP). Executive Team on Anti-Viral Treatment. J Viral Hepat 1998;5:389-97.

93. Wong VW, Wong GL, Yan KK, et al. Durability of peginterferon alfa-2b treatment at 5 years in patients with hepatitis B e antigenpositive chronic hepatitis B. Hepatology 2010;51:1945-53.

94. Fattovich G, Giustina G, Realdi G, Corrocher R, Schalm SW. Long-term outcome of hepatitis B e antigen-positive patients with compensated cirrhosis treated with interferon alfa. European Concerted Action on Viral Hepatitis (EUROHEP). Hepatology 1997;26:1338-42. 
95. Lin SM, Yu ML, Lee CM, et al. Interferon therapy in $\mathrm{HBeAg}$ positive chronic hepatitis reduces progression to cirrhosis and hepatocellular carcinoma. J Hepatol 2007;46:45-52.

96. Sonneveld MJ, Rijckborst V, Boucher CA, Hansen BE, Janssen HL. Prediction of sustained response to peginterferon alfa- $2 \mathrm{~b}$ for hepatitis B e antigen-positive chronic hepatitis B using on-treatment hepatitis B surface antigen decline. Hepatology 2010;52:1251-7.

97. Hansen BE, Buster EH, Steyerberg EW, Lesaffre E, Janssen HL. Prediction of the response to peg-interferon-alfa in patients with $\mathrm{HBe} A g$ positive chronic hepatitis $\mathrm{B}$ using decline of HBV DNA during treatment. J Med Virol 2010;82:1135-42.

98. Marcellin P, Lau GK, Bonino F, et al. Peginterferon alfa-2a alone, lamivudine alone, and the two in combination in patients with $\mathrm{HBeAg}$-negative chronic hepatitis B. N Engl J Med 2004;351:1206-17.

99. Marcellin P, Bonino F, Lau GK, et al. Sustained response of hepatitis $\mathrm{B}$ e antigen-negative patients 3 years after treatment with peginterferon alpha-2a. Gastroenterology 2009;136:2169-79, e1-4.

100. Marcellin P, Heathcote EJ, Buti M, et al. Tenofovir disoproxil fumarate versus adefovir dipivoxil for chronic hepatitis B. N Engl J Med 2008;359:2442-55.

101. Marcellin P, Buti M, Gane E, et al. Five years of treatment with tenofovir DF (TDF) for chronic hepatitis B (CHB) infection is associated with sustained viral suppression and significant regression of histological fibrosis and cirrhosis. 62nd Annual Meeting of the American Association for the Study of Liver Disease (AASLD 2011). Hepatology 2011;54(Suppl 4):A1375. (Abst).

102. Snow-Lampart A, Chappell B, Curtis M, et al. No resistance to tenofovir disoproxil fumarate detected after up to 144 weeks of therapy in patients monoinfected with chronic hepatitis B virus. Hepatology 2011;53:763-73.

103. van Bommel F, Wunsche T, Mauss S, et al. Comparison of adefovir and tenofovir in the treatment of lamivudine-resistant hepatitis B virus infection. Hepatology 2004:40:1421-5.

104. van Bommel F, de Man RA, Wedemeyer H, et al. Long-term efficacy of tenofovir monotherapy for hepatitis B virusmonoinfected patients after failure of nucleoside/nucleotide analogues. Hepatology 2010;51:73-80.

105. Chang TT, Gish RG, de Man R, et al. A comparison of entecavir and lamivudine for HBeAg-positive chronic hepatitis B. N Engl J Med 2006;354:1001-10.

106. Tenney DJ, Levine SM, Rose RE, et al. Clinical emergence of entecavir-resistant hepatitis $B$ virus requires additional substitutions in virus already resistant to Lamivudine. Antimicrob Agents Chemother 2004:48:3498-507.

107. Colonno RJ, Rose R, Baldick CJ, et al. Entecavir resistance is rare in nucleoside naive patients with hepatitis B. Hepatology 2006; 44:1656-65.

108. Chang T, Chao T, Kaymakoglu S, et al. Entecavir maintained virologic suppression through 3 years of treatment in antiviral-naive $\mathrm{HBeAg}$ positive patients (Abstract 223). 57th Annual Meting of the American Association for the Study of Liver Disease, Boston, October 27 to 31, 2006.

109. Lai CL, Shouval D, Lok AS, et al. Entecavir versus lamivudine for patients with HBeAg-negative chronic hepatitis B. N Engl J Med 2006;354:1011-20

110. Sherman M, Yurdaydin C, Simsek H, et al. Entecavir therapy for lamivudine-refractory chronic hepatitis B: Improved virologic, biochemical, and serology outcomes through 96 weeks. Hepatology 2008;48:99-108.

111. Lok AS, Lai CL, Leung N, et al. Long-term safety of lamivudine treatment in patients with chronic hepatitis B. Gastroenterology 2003;125:1714-22.

112. Lai CL, Dienstag J, Schiff E, et al. Prevalence and clinical correlates of YMDD variants during lamivudine therapy for patients with chronic hepatitis B. Clin Infect Dis 2003;36:687-96.

113. Papatheodoridis GV, Lampertico P, Manolakopoulos S, Lok A. Incidence of hepatocellular carcinoma in chronic hepatitis B patients receiving nucleos $(\mathrm{t})$ ide therapy: A systematic review. J Hepatol 2010;53:348-56.

114. Liaw YF, Sung JJ, Chow WC, et al. Lamivudine for patients with chronic hepatitis B and advanced liver disease. N Engl J Med 2004;351:1521-31.

115. Hui CK, Zhang HY, Bowden S, et al. 96 weeks combination of adefovir dipivoxil plus emtricitabine vs. adefovir dipivoxil monotherapy in the treatment of chronic hepatitis B. J Hepatol 2008;48:714-20.

116. Marcellin P, Chang TT, Lim SG, et al. Adefovir dipivoxil for the treatment of hepatitis B e antigen-positive chronic hepatitis B. N Engl J Med 2003;348:808-16.

117. Lampertico P, Vigano M, Manenti E, Iavarone M, Lunghi G, Colombo M. Adefovir rapidly suppresses hepatitis B in HBeAgnegative patients developing genotypic resistance to lamivudine. Hepatology 2005;42:1414-9.

118. Lai CL, Gane E, Liaw YF, et al. Telbivudine versus lamivudine in patients with chronic hepatitis B. N Engl J Med 2007;357:2576-88.

119. Liaw YF, Gane E, Leung N, et al. 2-Year GLOBE trial results: Telbivudine is superior to lamivudine in patients with chronic hepatitis B. Gastroenterology 2009;136:486-95.

120. Han GR, Cao MK, Zhao W, et al. A prospective and open-label study for the efficacy and safety of telbivudine in pregnancy for the prevention of perinatal transmission of hepatitis $B$ virus infection. J Hepatol 2011;55:1215-21.

121. Lim SG, Ng TM, Kung N, et al. A double-blind placebo-controlled study of emtricitabine in chronic hepatitis B. Arch Intern Med 2006;166:49-56.

122. Gish RG, Trinh H, Leung N, et al. Safety and antiviral activity of emtricitabine (FTC) for the treatment of chronic hepatitis B infection: A two-year study. J Hepatol 2005;43:60-6.

123. Peters MG, Hann $\mathrm{Hw} \mathrm{H}$, Martin P, et al. Adefovir dipivoxil alone or in combination with lamivudine in patients with lamivudineresistant chronic hepatitis B. Gastroenterology 2004;126:91-101.

124. Lai CL, Leung N, Teo EK, et al. A 1-year trial of telbivudine, lamivudine, and the combination in patients with hepatitis B e antigen-positive chronic hepatitis B. Gastroenterology 2005; 129:528-36.

125. Lok A, Trinh H, Carosi G. Entecavir (ETV) monotherapy for 96 weeks is comparable to combination therapy with ETV plus tenofovir (TDF) in nucleos(t)ide-naive patients with chronic hepatitis $\mathrm{B}(\mathrm{CHB})$ : The BE-LOW study. 62nd Annual Meeting of the American Association for the Study of Liver Disease (AASLD 2011). Hepatology 2011;54(Suppl 4):223. (Abst).

126. Liaw YF, Sheen IS, Lee CM, A et al. Tenofovir disoproxil fumarate (TDF), emtricitabine/TDF, and entecavir in patients with decompensated chronic hepatitis B liver disease. Hepatology 2011:53:62-72

127. Keeffe EB, Zeuzem S, Koff RS, et al. Report of an international workshop: Roadmap for management of patients receiving oral therapy for chronic hepatitis B. Clin Gastroenterol Hepatol 2007;5:890-7.

128. Lok AS, Zoulim F, Locarnini S, et al. Antiviral drug-resistant HBV: Standardization of nomenclature and assays and recommendations for management. Hepatology 2007;46:254-65.

129. Zoulim F. Mechanism of viral persistence and resistance to nucleoside and nucleotide analogs in chronic hepatitis B virus infection. Antiviral Res 2004;64:1-15.

130. Lok AS, Zoulim F, Locarnini S, et al. Monitoring drug resistance in chronic hepatitis B virus (HBV)-infected patients during lamivudine therapy: Evaluation of performance of INNO-LiPA HBV DR assay. J Clin Microbiol 2002;40:3729-34.

131. Fung SK, Andreone P, Han SH, et al. Adefovir-resistant hepatitis B can be associated with viral rebound and hepatic decompensation. J Hepatol 2005;43:937-43.

132. Dienstag JL, Wei LJ, Xu D, Kreter B. Cross-study analysis of the relative efficacies of oral antiviral therapies for chronic hepatitis B infection in nucleoside-naive patients. Clin Drug Investig 2007;27:35-49.

133. Lai C, Leung N, Teo E. One-year trial of telbivudine, lamivudine, and the combination in patients with hepatitis $\mathrm{B}$ e antigen-positive chronic hepatitis B. Gastroenterology 2005;129:528.

134. Lee YS, Suh DJ, Lim YS, et al. Increased risk of adefovir resistance in patients with lamivudine-resistant chronic hepatitis B after 48 weeks of adefovir dipivoxil monotherapy. Hepatology 2006;43:1385-91

135. Fung SK, Chae HB, Fontana RJ, et al. Virologic response and resistance to adefovir in patients with chronic hepatitis B. J Hepatol 2006;44:283-90.

136. Colonno R, Rose R, Polkornowski K, Baldick C, Klesczewski K, Tenney D. Assessment at three years shows high barrier to resistance is maintained in entecavir treated nucleoside naive patients while resistance emergence increases over time in lamuvidine refractory patients. Hepatology 2006;44:229A (Abst). 
137. Liaw YF, Lee CM, Chien RN, Yeh CT. Switching to adefovir monotherapy after emergence of lamivudine-resistant mutations in patients with liver cirrhosis. J Viral Hepat 2006;13:250-5.

138. Tenney DJ, Rose RE, Baldick CJ, et al. Two-year assessment of entecavir resistance in Lamivudine-refractory hepatitis B virus patients reveals different clinical outcomes depending on the resistance substitutions present. Antimicrob Agents Chemother 2007;51:902-11.

139. Sheldon J, Camino N, Rodes B, et al. Selection of hepatitis B virus polymerase mutations in HIV-coinfected patients treated with tenofovir. Antivir Ther 2005;10:727-34.

140. Beasley R. Hepatitis B. The major etiology of hepatocellular carcinoma. Cancer 1988;61:1942-56.

141. McMahon BJ, Alberts SR, Wainwright RB, Bulkow L, Lanier AP. Hepatitis B-related sequelae. Prospective study in 1400 hepatitis B surface antigen-positive Alaska native carriers. Arch Intern Med 1990;150:1051-4.

142. Realdi G, Fattovich G, Hadziyannis S, et al. Survival and prognostic factors in 366 patients with compensated cirrhosis type B: a multicenter study. The Investigators of the European Concerted Action on Viral Hepatitis (EUROHEP). J Hepatol 1994:21:656-66.

143. Chiaramonte M, Stroffolini T, Vian A, et al. Rate of incidence of hepatocellular carcinoma in patients with compensated viral cirrhosis. Cancer 1999;85:2132-7.

144. Yang HI, Sherman M, Su J, et al. Nomograms for risk of hepatocellular carcinoma in patients with chronic hepatitis B virus infection. J Clin Oncol 2010;28:2437-44.

145. Yang HI, Yuen MF, Chan HL, et al. Risk estimation for hepatocellular carcinoma in chronic hepatitis B (REACH-B): Development and validation of a predictive score. Lancet Oncol 2011;12:568-74.

146. Trevisani F, D'Intino PE, Morselli-Labate AM, et al. Serum alphafetoprotein for diagnosis of hepatocellular carcinoma in patients with chronic liver disease: Influence of $\mathrm{HBsAg}$ and anti-HCV status. J Hepatol 2001;34:570-5.

147. Villeneuve JP, Condreay LD, Willems B, et al. Lamivudine treatment for decompensated cirrhosis resulting from chronic hepatitis B. Hepatology 2000;31:207-10.

148. Sponseller CA, Bacon BR, Di Bisceglie AM. Clinical improvement in patients with decompensated liver disease caused by hepatitis B after treatment with lamivudine. Liver Transpl 2000;6:715-20.

149. Kuwahara R, Kumashiro R, Inoue H, et al. Adefovir dipivoxil as a treatment for hepatic failure caused by lamivudine-resistant HBV strains. Dig Dis Sci 2004;49:300-3.

150. Alter MJ. Epidemiology of viral hepatitis and HIV co-infection. J Hepatol 2006;44(1 Suppl):S6-9.

151. Hall HI, Geduld J, Boulos D, et al. Epidemiology of HIV in the United States and Canada: Current status and ongoing challenges. J Acquir Immune Defic Syndr 2009;(51 Suppl 1):S13-20.

152. Yang Q, Boulos D, Yan P, et al. Estimates of the number of prevalent and incident human immunodeficiency virus (HIV) infections in Canada, 2008. Can J Public Health 2010;101:486-90.

153. Thio CL. Hepatitis B and human immunodeficiency virus coinfection. Hepatology 2009;49(5 Suppl):S138-45.

154. Palella FJ Jr, Baker RK, Moorman AC, et al. Mortality in the highly active antiretroviral therapy era: Changing causes of death and disease in the HIV outpatient study. J Acquir Immune Defic Syndr 2006;43:27-34.

155. Thio C, Seaberg E, Skolasky RJ, et al. HIV-1, hepatitis B virus, and risk of liver-related mortality in the Multicenter Cohort Study (MACS). Lancet 2002;360:1921-6.

156. Nikolopoulos GK, Paraskevis D, Hatzitheodorou E, et al. Impact of hepatitis B virus infection on the progression of AIDS and mortality in HIV-infected individuals: A cohort study and meta-analysis. Clin Infect Dis 2009;48:1763-71.

157. Lin K, Karwowska S, Lam E, Limoli K, Evans TG, Avila C. Telbivudine exhibits no inhibitory activity against HIV-1 clinical isolates in vitro. Antimicrob Agents Chemother 2010;54:2670-3.

158. McMahon MA, Jilek BL, Brennan TP, et al. The HBV drug entecavir - effects on HIV-1 replication and resistance. N Engl J Med 2007;356:2614-21.

159. Low E, Cox A, Atkins M, Nelson M. Telbivudine has activity against HIV-1. AIDS 2009;23:546-7.

160. de Vries-Sluijs TE, Reijnders JG, Hansen BE, et al. Long-term therapy with tenofovir is effective for patients co-infected with human immunodeficiency virus and hepatitis $B$ virus. Gastroenterology 2010;139:1934-41.
161. Matthews GV, Bartholomeusz A, Locarnini S, et al. Characteristics of drug resistant $\mathrm{HBV}$ in an international collaborative study of HIV-HBV-infected individuals on extended lamivudine therapy. AIDS 2006;20:863-70.

162. Thio CL. Virology and clinical sequelae of drug-resistant HBV in HIV-HBV-coinfected patients on highly active antiretroviral therapy. Antivir Ther 2010;15:487-91.

163. Pessoa MG, Gazzard B, Huang AK, et al. Efficacy and safety of entecavir for chronic HBV in HIV/HBV coinfected patients receiving lamivudine as part of antiretroviral therapy. AIDS 2008;22:1779-87.

164. Rockstroh JK, Bhagani S, Benhamou Y, et al. European AIDS Clinical Society (EACS) guidelines for the clinical management and treatment of chronic hepatitis B and C coinfection in HIVinfected adults. HIV Med 2008;9:82-8.

165. Thompson MA, Aberg JA, Cahn P, et al. Antiretroviral treatment of adult HIV infection: 2010 recommendations of the International AIDS Society-USA panel. JAMA 2010;304:321-33.

166. Asboe D, Aitken C, Boffito M, et al. British HIV Association guidelines for the routine investigation and monitoring of adult HIV-1-infected individuals 2011. HIV Med 2012;13:1-44.

167. Bellini C, Keiser O, Chave JP, et al. Liver enzyme elevation after lamivudine withdrawal in HIV-hepatitis B virus co-infected patients: The Swiss HIV Cohort Study. HIV Med 2009;10:12-8.

168. Bessesen M, Ives D, Condreay L, Lawrence S, Sherman KE. Chronic active hepatitis B exacerbations in human immunodeficiency virus-infected patients following development of resistance to or withdrawal of lamivudine. Clin Infect Dis 1999;28:1032-5.

169. Soriano V, Vispo E, Barreiro P. New 2011 updated DHHS antiretroviral treatment guidelines and chronic hepatitis B. AIDS 2011;25:1013-4.

170. Benhamou Y. Hepatitis B in the HIV-coinfected patient. J Acquir Immune Defic Syndr 2007;45(Suppl 2):S57-65; discussion S6-7.

171. Rouanet I, Peyriere H, Mauboussin JM, Terrail N, Vincent D. Acute clinical hepatitis by immune restoration in a human immunodeficiency virus/hepatitis $B$ virus co-infected patient receiving antiretroviral therapy. Eur J Gastroenterol Hepatol 2003;15:95-7.

172. Woodward CL, Hall AM, Williams IG, et al. Tenofovir-associated renal and bone toxicity. HIV Med 2009;10:482-7.

173. Geretti AM, Doyle T. Immunization for HIV-positive individuals. Curr Opin Infect Dis 2010;23:32-8.

174. Gaeta GB, Stornaiuolo G, Precone DF, et al. Epidemiological and clinical burden of chronic hepatitis B virus/hepatitis $C$ virus infection. A multicenter Italian study. J Hepatol 2003;39:1036-41.

175. Zhou J, Dore GJ, Zhang F, Lim PL, Chen YM. Hepatitis B and C virus coinfection in The TREAT Asia HIV Observational Database. J Gastroenterol Hepatol 2007;22:1510-8.

176. Fattovich G, Tagger A, Brollo L, et al. Hepatitis $C$ virus infection in chronic hepatitis B virus carriers. J Infect Dis 1991;163:400-2.

177. Crespo J, Lozano JL, de la Cruz F, et al. Prevalence and significance of hepatitis $\mathrm{C}$ viremia in chronic active hepatitis B. Am J Gastroenterol 1994;89:1147-51.

178. Fong TL, Di Bisceglie AM, Waggoner JG, Banks SM, Hoofnagle $\mathrm{JH}$. The significance of antibody to hepatitis $\mathrm{C}$ virus in patients with chronic hepatitis B. Hepatology 1991;14:64-7.

179. Mohamed Ael S, al Karawi MA, Mesa GA. Dual infection with hepatitis C and B viruses: Clinical and histological study in Saudi patients. Hepatogastroenterology 1997;44:1404-6.

180. Zarski JP, Bohn B, Bastie A, et al. Characteristics of patients with dual infection by hepatitis B and C viruses. J Hepatol 1998;28:27-33.

181. Benvegnu L, Fattovich G, Noventa F, et al. Concurrent hepatitis B and $C$ virus infection and risk of hepatocellular carcinoma in cirrhosis. A prospective study. Cancer 1994;74:2442-8.

182. Donato F, Boffetta P, Puoti M. A meta-analysis of epidemiological studies on the combined effect of hepatitis $\mathrm{B}$ and $\mathrm{C}$ virus infections in causing hepatocellular carcinoma. Int J Cancer 1998;75:347-54.

183. Lee LP, Dai CY, Chuang WL, et al. Comparison of liver histopathology between chronic hepatitis $\mathrm{C}$ patients and chronic hepatitis B and C-coinfected patients. J Gastroenterol Hepatol 2007;22:515-7

184. Eyre NS, Phillips RJ, Bowden S, et al. Hepatitis B virus and hepatitis $\mathrm{C}$ virus interaction in Huh-7 cells. J Hepatol 2009;51:446-57.

185. Bellecave P, Gouttenoire J, Gajer M, et al. Hepatitis B and C virus coinfection: A novel model system reveals the absence of direct viral interference. Hepatology 2009;50:46-55. 
186. Raimondo G, Brunetto MR, Pontisso P, et al. Longitudinal evaluation reveals a complex spectrum of virological profiles in hepatitis $\mathrm{B} /$ hepatitis $\mathrm{C}$ virus-coinfected patients. Hepatology 2006;43:100-7.

187. Sagnelli E, Coppola N, Scolastico C, et al. Virologic and clinical expressions of reciprocal inhibitory effect of hepatitis B, C, and Delta viruses in patients with chronic hepatitis. Hepatology 2000;32:1106-10.

188. Liu CJ, Chuang WL, Lee CM, et al. Peginterferon alfa-2a plus ribavirin for the treatment of dual chronic infection with hepatitis B and C viruses. Gastroenterology 2009;136:496-504, e3.

189. Yu JW, Sun LJ, Zhao YH, Kang P, Gao J, Li SC. Analysis of the efficacy of treatment with peginterferon alpha-2a and ribavirin in patients coinfected with hepatitis $B$ virus and hepatitis $C$ virus. Liver Int 2009;29:1485-93.

190. Potthoff A, Wedemeyer H, Boecher WO, et al. The HEP-NET B/C co-infection trial: A prospective multicenter study to investigate the efficacy of pegylated interferon-alpha2b and ribavirin in patients with HBV/HCV co-infection. J Hepatol 2008;49:688-94.

191. Stevens CE, Toy PT, Tong MJ, et al. Perinatal hepatitis B virus transmission in the United States. Prevention by passive-active immunization. JAMA 1985;253:1740-5.

192. Ip HM, Lelie PN, Wong VC, Kuhns MC, Reesink HW. Prevention of hepatitis B virus carrier state in infants according to maternal serum levels of HBV DNA. Lancet 1989;1:406-10.

193. Chen HL, Lin LH, Hu FC, et al. Effects of maternal screening and universal immunization to prevent mother-to-infant transmission of HBV. Gastroenterology 2012;142:773-81, e2.

194. Wiseman E, Fraser MA, Holden S, et al. Perinatal transmission of hepatitis B virus: An Australian experience. Med J Aust 2009; 190:489-92.

195. Andre FE, Zuckerman AJ. Review: Protective efficacy of hepatitis B vaccines in neonates. J Med Virol 1994:44:144-51.

196. del Canho R, Grosheide PM, Mazel JA, et al. Ten-year neonatal hepatitis B vaccination program, The Netherlands, 1982-1992: Protective efficacy and long-term immunogenicity. Vaccine 1997; 15:1624-30.

197. Singh AE, Plitt SS, Osiowy C, et al. Factors associated with vaccine failure and vertical transmission of hepatitis $\mathrm{B}$ among a cohort of Canadian mothers and infants. J Viral Hepat 2011;18:468-73.

198. Pan C, Han GR, Zhao W, Xu C, Ge C. Virologic factors associated with failure to passive-active immunoprophylaxis in infants with HBsAg-positive at birth. Hepatology 2011;54(Suppl 4):878A.

199. Han GR, Zhao W, Xu CL, Ge CY, Jiang HX, Pan C. Risk factors associated with perinatal infection of HBV in infants who born to $\mathrm{HBsAg}$ and $\mathrm{HBeAg}$ positive mothers. Hepatology 2011;54(Suppl 4):444A.

200. Xu WM, Cui YT, Wang L, et al. Lamivudine in late pregnancy to prevent perinatal transmission of hepatitis $B$ virus infection: A multicentre, randomized, double-blind, placebo-controlled study. J Viral Hepat 2009;16:94-103.

201. van Zonneveld M, van Nunen AB, Niesters HG, de Man RA, Schalm SW, Janssen HL. Lamivudine treatment during pregnancy to prevent perinatal transmission of hepatitis B virus infection. J Viral Hepat 2003;10:294-7.

202. Han GR, Jiang H, Zhao W, Ge C, Xu C, Pan C. Lamivudine use in the 2 nd or 3rd trimester of pregnancy has similar efficacy in preventing vertical transmission (VT) of chronic hepatitis B (CHB) in highly viremic mothers. Hepatology 2011;54:479A.

203. U.S. Food and Drug Administration Summary of Proposed Rule on Pregnancy and Lactation Labeling. 2008:30831.

204. Antiretroviral Pregnancy Registry International Interim Report for 1 January 1989 through 31 July 2011. Wilmington: Registry Coordinating Center; 2011.

205. Viread (Tenofovir DF) Prescribing Information. Gilead Sciences Incorporated. Foster City, CA; Revised January 2012.

206. Tyzeka (Telbivudine) prescribing information. Novartis Pharmaceuticals Corporation. East Hanover, New Jersey; Revised December 2011.

207. Pol S, Corouge M, Fontaine $\mathrm{H}$. Hepatitis $B$ virus infection and pregnancy. Clin Res Hepatol Gastroenterol 2011;35:618-22.

208. Benaboud S, Pruvost A, Coffie PA, et al. Concentrations of tenofovir and emtricitabine in breast milk of HIV-1-infected women in Abidjan, Cote d'Ivoire, in the ANRS 12109 TEmAA Study, Step 2. Antimicrob Agents Chemother 2011;55:1315-7.

209. Gartner LM, Morton J, Lawrence RA, et al. Breastfeeding and the use of human milk. Pediatrics 2005;115:496-506.
210. Palda VA, Guise JM, Wathen CN. Interventions to promote breastfeeding: Applying the evidence in clinical practice. CMAJ 2004;170:976-8.

211. Hill JB, Sheffield JS, Kim MJ, Alexander JM, Sercely B, Wendel GD. Risk of hepatitis B transmission in breast-fed infants of chronic hepatitis B carriers. Obstet Gynecol 2002;99:1049-52.

212. Tseng RY, Lam CW, Tam J. Breastfeeding babies of HBsAg-positive mothers. Lancet 1988;2:1032.

213. de Martino M, Appendino C, Resti M, Rossi ME, Muccioli AT, Vierucci A. Should hepatitis B surface antigen positive mothers breast feed? Arch Dis Child 1985;60:972-4.

214. Kazim SN, Wakil SM, Khan LA, Hasnain SE, Sarin SK. Vertical transmission of hepatitis B virus despite maternal lamivudine therapy. Lancet 2002;359:1488-9.

215. Cacoub P, Terrier B. Hepatitis B-related autoimmune manifestations. Rheum Dis Clin North Am 2009;35:125-37.

216. Han SH. Extrahepatic manifestations of chronic hepatitis B. Clin Liver Dis 2004;8:403-18.

217. Kim JD, Sherker AH. Antiviral therapy: Role in the management of extrahepatic diseases. Gastroenterol Clin North Am 2004;33:693-708, xi

218. Yi Z, Jie YW, Nan Z. The efficacy of anti-viral therapy on hepatitis $B$ virus-associated glomerulonephritis: A systematic review and meta-analysis. Ann Hepatol 2011;10:165-73.

219. Gan SI, Devlin SM, Scott-Douglas NW, Burak KW. Lamivudine for the treatment of membranous glomerulopathy secondary to chronic hepatitis B infection. Can J Gastroenterol 2005;19:625-9.

220. Ng YY, Yang WC, Lee ST. Long-term lamivudine therapy in hepatitis B-associated membranous nephropathy? Kidney Int 2006;69:776

221. Tang S, Lai FM, Lui YH, et al. Lamivudine in hepatitis B-associated membranous nephropathy. Kidney Int 2005;68:1750-8.

222. Shapiro RJ, Steinbrecher UP, Magil A. Remission of nephrotic syndrome of HBV-associated membranous glomerulopathy following treatment with interferon. Am J Nephrol 1995;15:343-7.

223. Giboa N, Neigut D. Interferon treatment of hepatitis B-associated membranous glomerulonephritis and nephrotic syndrome. Pediatr Nephrol 1993;7:328-9.

224. Gupta S, Piraka C, Jaffe M. Lamivudine in the treatment of polyarteritis nodosa associated with acute hepatitis B. N Engl J Med 2001;344:1645-6.

225. Deleaval P, Stadler P, Descombes E, et al. Life-threatening complications of hepatitis $B$ virus-related polyarteritis nodosa developing despite interferon-alpha2b therapy: Successful treatment with a combination of interferon, lamivudine, plasma exchanges and steroids. Clin Rheumatol 2001;20:290-2.

226. Mesquita M, Lasser L, Langlet P. Long-term (7-year-) treatment with lamivudine monotherapy in $\mathrm{HBV}$-associated glomerulonephritis. Clin Nephrol 2008;70:69-71.

227. Ikee R, Ishioka K, Oka M, et al. Hepatitis B virus-related membranous nephropathy treated with entecavir. Nephrology (Carlton) 2010;15:266.

228. Hoofnagle JH. Reactivation of hepatitis B. Hepatology 2009;49(5 Suppl):S156-65.

229. Roche B, Samuel D. The difficulties of managing severe hepatitis B virus reactivation. Liver Int 2011;31(Suppl 1):104-10.

230. Raimondo G, Pollicino T, Romano L, Zanetti AR. A 2010 update on occult hepatitis B infection. Pathol Biol (Paris) 2010;58:254-7.

231. Raimondo G, Allain JP, Brunetto MR, et al. Statements from the Taormina expert meeting on occult hepatitis $B$ virus infection. J Hepatol 2008;49:652-7.

232. Zhong S, Yeo W, Schroder C, et al. High hepatitis B virus (HBV) DNA viral load is an important risk factor for HBV reactivation in breast cancer patients undergoing cytotoxic chemotherapy. J Viral Hepat 2004;11:55-9.

233. Bagaglio S, Porrino L, Lazzarin A, Morsica G. Molecular characterization of occult and overt hepatitis B (HBV) infection in an HIV-infected person with reactivation of HBV after antiretroviral treatment interruption. Infection 2010;38:417-21.

234. Proia LA, Ngui SL, Kaur S, Kessler HA, Trenholme GM. Reactivation of hepatitis B in patients with human immunodeficiency virus infection treated with combination antiretroviral therapy. Am J Med 2000;108:249-51.

235. Manegold C, Hannoun C, Wywiol A, et al. Reactivation of hepatitis $\mathrm{B}$ virus replication accompanied by acute hepatitis in 
patients receiving highly active antiretroviral therapy. Clin Infect Dis 2001;32:144-8.

236. Moses SE, Lim Z, Zuckerman MA. Hepatitis B virus infection: Pathogenesis, reactivation and management in hematopoietic stem cell transplant recipients. Expert Rev Anti Infect Ther 2011;9:891-9.

237. Ohishi W, Chayama K. Prevention of hepatitis B virus reactivation in immunosuppressive therapy or chemotherapy. Clin Exp Nephrol 2011;15:634-40.

238. Papamichalis P, Alexiou A, Boulbou M, Dalekos GN, Rigopoulou EI. Reactivation of resolved hepatitis $B$ virus infection after immunosuppression: Is it time to adopt pre-emptive therapy? Clin Res Hepatol Gastroenterol 2012;36:84-93.

239. Arama V, Munteanu D, Olaru I, et al. Reactivation of HBV infection in low grade lymphoma patient. Rom J Intern Med 2011;49:67-73.

240. Kusumoto S, Tanaka Y, Ueda R, Mizokami M. Reactivation of hepatitis $B$ virus following rituximab-plus-steroid combination chemotherapy. J Gastroenterol 2011;46:9-16.

241. Palmore TN, Shah NL, Loomba R, et al. Reactivation of hepatitis B with reappearance of hepatitis B surface antigen after chemotherapy and immunosuppression. Clin Gastroenterol Hepatol 2009;7:1130-7.

242. Dhedin N, Douvin C, Kuentz M, et al. Reverse seroconversion of hepatitis $\mathrm{B}$ after allogeneic bone marrow transplantation: A retrospective study of 37 patients with pretransplant anti-HBs and anti-HBc. Transplantation 1998;66:616-9.

243. Waite J, Gilson RJ, Weller IV, et al. Hepatitis B virus reactivation or reinfection associated with HIV-1 infection. AIDS 1988;2:443-8.

244. Hwang J, Fisch M, Zhang H, et al. Reactivation of hepatitis B infection among patients with cancer. Hepatology 2011;54 (Suppl 4):445A.

245. Vassiliadis T, Garipidou V, Tziomalos K, Perifanis V, Giouleme O, Vakalopoulou S. Prevention of hepatitis B reactivation with lamivudine in hepatitis B virus carriers with hematologic malignancies treated with chemotherapy - a prospective case series. Am J Hematol 2005;80:197-203.

246. Shibolet O, Ilan Y, Gillis S, Hubert A, Shouval D, Safadi R. Lamivudine therapy for prevention of immunosuppressive-induced hepatitis $B$ virus reactivation in hepatitis $B$ surface antigen carriers. Blood 2002;100:391-6.

247. Katz LH, Fraser A, Gafter-Gvili A, Leibovici L, Tur-Kaspa R. Lamivudine prevents reactivation of hepatitis $B$ and reduces mortality in immunosuppressed patients: Systematic review and meta-analysis. J Viral Hepat 2008;15:89-102.

248. Jang JW, Choi JY, Bae SH, et al. A randomized controlled study of preemptive lamivudine in patients receiving transarterial chemolipiodolization. Hepatology 2006;43:233-40.
249. Hsu C, Hsiung CA, Su IJ, et al. A revisit of prophylactic lamivudine for chemotherapy-associated hepatitis B reactivation in non-Hodgkin's lymphoma: A randomized trial. Hepatology 2008;47:844-53.

250. Lau GK, Yiu HH, Fong DY, et al. Early is superior to deferred preemptive lamivudine therapy for hepatitis $\mathrm{B}$ patients undergoing chemotherapy. Gastroenterology 2003;125:1742-9.

251. Watanabe M, Shibuya A, Takada J, et al. Entecavir is an optional agent to prevent hepatitis B virus (HBV) reactivation: A review of 16 patients. Eur J Intern Med 2010;21:333-7.

252. Brost S, Schnitzler P, Stremmel W, Eisenbach C. Entecavir as treatment for reactivation of hepatitis B in immunosuppressed patients. World J Gastroenterol 2010;16:5447-51.

253. Milazzo L, Corbellino M, Foschi A, et al. Late onset of hepatitis B virus reactivation following hematopoietic stem cell transplantation: Successful treatment with combined entecavir plus tenofovir therapy. Transpl Infect Dis 2012;14:95-8.

254. Vallet-Pichard A, Fontaine H, Mallet V, Pol S. Viral hepatitis in solid organ transplantation other than liver. J Hepatol 2011;55:474-82.

255. Management of healthcare workers infected with hepatitis B virus, hepatitis $C$ virus, human immunodeficiency virus, or other bloodborne pathogens. AIDS/TB Committee of the Society for Healthcare Epidemiology of America. Infect Control Hosp Epidemiol 1997;18:349-63.

256. Henderson DK, Dembry L, Fishman NO, et al. SHEA guideline for management of healthcare workers who are infected with hepatitis B virus, hepatitis $\mathrm{C}$ virus, and/or human immunodeficiency virus. Infect Control Hosp Epidemiol 2010;31:203-32.

257. Gunson RN, Shouval D, Roggendorf M, et al. Hepatitis B virus (HBV) and hepatitis $\mathrm{C}$ virus (HCV) infections in health care workers (HCWs): Guidelines for prevention of transmission of HBV and HCV from HCW to patients. J Clin Virol 2003;27:213-30.

258. Niro GA, Smedile A. Current concept in the pathophysiology of hepatitis delta infection. Curr Infect Dis Rep 2012;14:9-14.

259. Wedemeyer $H$, Heidrich B, Manns MP. Hepatitis D virus infection - not a vanishing disease in Europe! Hepatology 2007;45:1331-2; author reply 2-3.

260. Degertekin H, Yalcin K, Yakut M. The prevalence of hepatitis delta virus infection in acute and chronic liver diseases in Turkey: An analysis of clinical studies. Turk J Gastroenterol 2006;17:25-34.

261. Abbas Z, Khan MA, Salih M, Jafri W. Interferon alpha for chronic hepatitis D. Cochrane Database Syst Rev 2011;12:CD006002.

262. Wedemeyer H, Yurdaydin C, Dalekos GN, et al. Peginterferon plus adefovir versus either drug alone for hepatitis delta. $\mathrm{N}$ Engl J Med 2011;364:322-31.

263. Wong D, Cheung A, O’Rourke K. Effect of alpha-interferon treatment in patients with hepatitis B e antigen-positive chronic hepatitis B. A meta-analysis. Ann Intern Med 1993;119:312-23. 


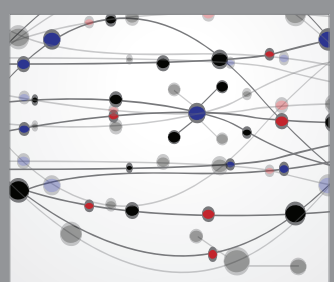

The Scientific World Journal
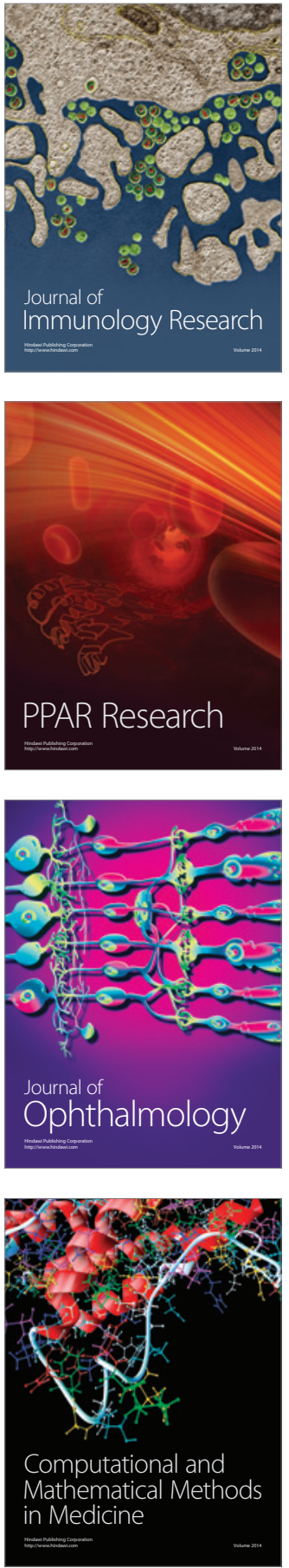

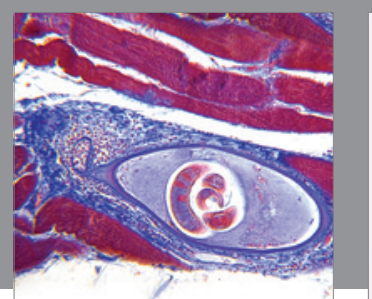

Gastroenterology Research and Practice

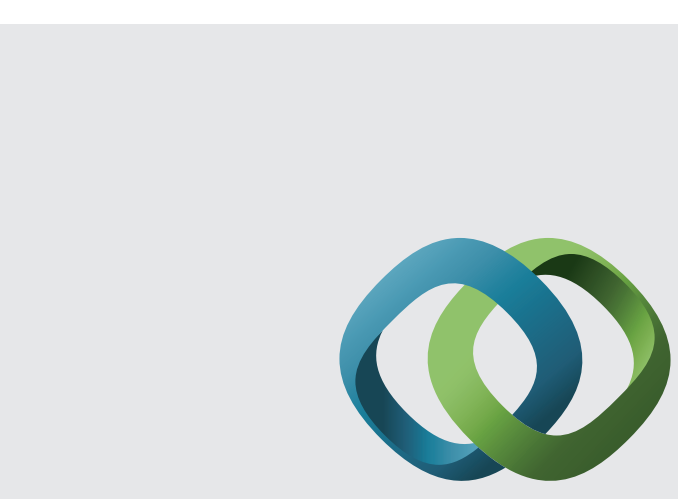

\section{Hindawi}

Submit your manuscripts at

http://www.hindawi.com
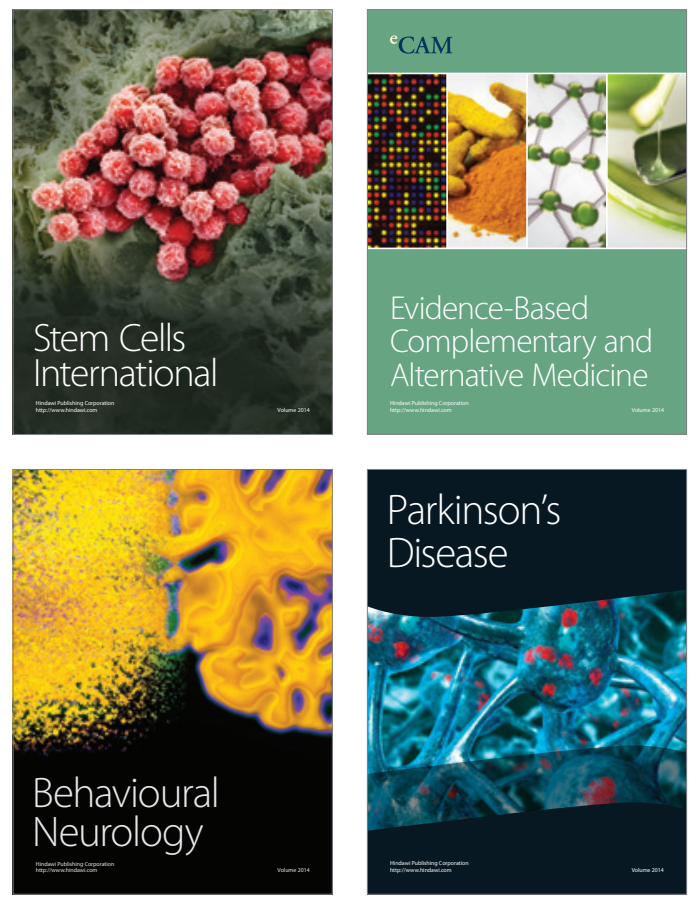
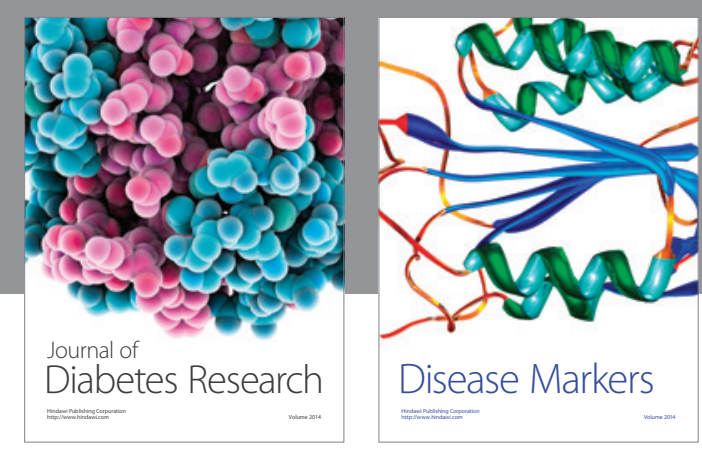

Disease Markers
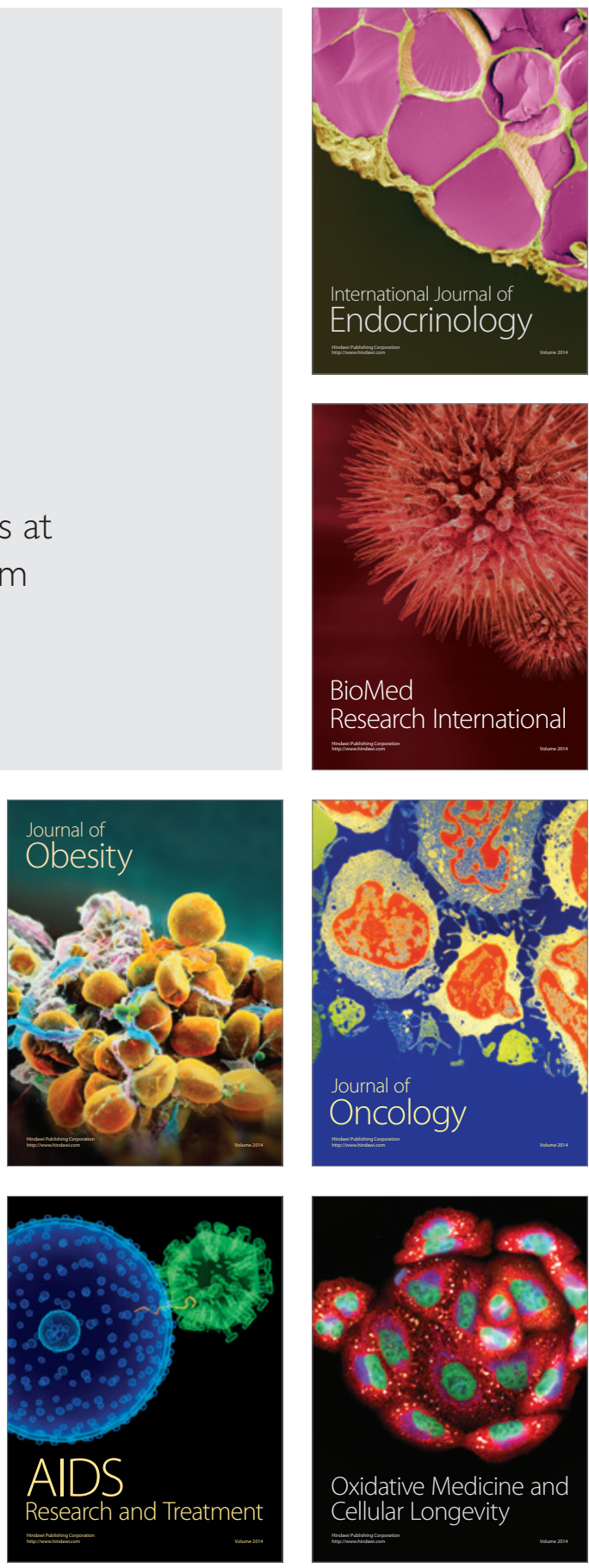